\title{
New insights into the seasonal feeding ecology of Pecten maximus using pigments, fatty acids and sterols analyses
}

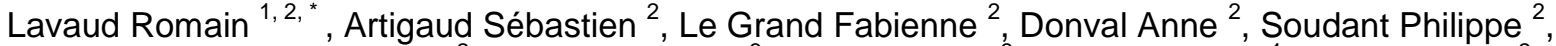 \\ Flye-Sainte-Marie Jonathan ${ }^{2}$, Strohmeier Tore ${ }^{3}$, Strand Øivind ${ }^{3}$, Leynaert Aude ${ }^{4}$, Beker Beatriz $^{2}$, \\ Chatterjee Arnab ${ }^{2}$, Jean Fred ${ }^{2}$
}

\footnotetext{
${ }^{1}$ Fisheries and Oceans Canada/Pêches et Océans Canada, Gulf center/Centre du Golfe, Moncton, NB E1C 9B6, Canada

${ }^{2}$ Laboratoire des sciences de l'environnement marin (UMR6539 CNRS/UBO/IRD/lfremer), Institut

Universitaire Européen de la Mer, Université de Brest, 29280 Plouzané, France

${ }^{3}$ Institute of Marine Research (IMR), 5005 Bergen, Norway

* Corresponding author : Romain Lavaud, email address : romain.lavaud@dfo-mpo.gc.ca
}

\begin{abstract}
:
We combined the use of pigments, fatty acids and sterols as biomarkers of the seasonal variation in food sources of the great scallop Pecten maximus. From March to October 2011, on a biweekly to twice-weekly basis, scallops and seawater from the water column and the water-sediment interface were collected in the Bay of Brest (Brittany, France). Pigment compositions in the seawater and in the stomach and rectum content of the scallops were analyzed by HPLC. Fatty acids and sterols from digestive gland (DG) tissue were analyzed by gas chromatography. Potential relationships between the temporal proportion of each marker in the environment and in the digestive tract were tested using multivariate analysis. Proportions of diatoms and Dinophyceae biomarkers alternated in the digestive tract of $P$. maximus. This switch of feeding was confirmed by the polar lipid composition of the DG. Peridinin, characterizing Dinophyceae, occurred in high proportions in the digestive tract compared to the low ambient concentration, suggesting a selection of this microalgae group by the scallop. Chlorophyceae and green macroalgae tracers were found in low proportions, suggesting they were not actually ingested. Markers of Prymnesiophyceae were also observed at significant levels. Cyanobacteria tracers showed that this microalgae class was not ingested by the scallops during monitoring but may be of higher importance during winter. Switching from one food source to another as well as selectivity in feeding are discussed relative to the season.
\end{abstract}

Keywords: Trophic ecology, Food sources, Pigments, Fatty acids, Trophic marker, Phytoplankton, Pecten maximus 


\section{Introduction}

Scallops, such as Pecten maximus (Linnaeus, 1758), are sessile, suspension-feeding animals living halfburied on the sea floor. They rely on the availability of trophic resources in the nearby water to obtain their food. In coastal environments, factors such as temperature, light, riverine inputs, salinity, tide and currents influence seawater primary production. The availability of food depends on the strong seasonality of these hydrological and biochemical conditions; therefore, suspension-feeding bivalves must have evolved to develop a plastic trophic niche (Rossi et al. 2004, Nérot et al. 2012). Scallops may thus feed on pelagic and benthic microalgae, protozoans, microzooplankton, dissolved organic carbon and detrital organic matter (Shumway et al. 1987, Lorrain et al. 2002, Mac Donald et al. 2006, Lavaud et al. 2014, Aya \& Kudo 2017). A recent study has confirmed this diversified diet (Nérot et al. 2012), yet only qualitatively.

Studies aiming at tracing the potential trophic sources of an organism use various chemical, biological, biochemical or physiological indicators of the prey items in the environment and inside the organisms. Among these indicators, stable isotopes are often used (Rossi et al. 2004, Bode et al. 2006, Marín Leal et al. 2008). Although they are able to discriminate between taxa at different trophic levels (benthic vs. planktonic microalgae for example), their low turnover is sometimes insufficient to distinguish short-term changes in the diet of the consumer. Pigments and lipids (fatty acids [FAs] and sterols), on the other hand, have long been used to characterize the class, genus and even species of microalgae (Jeffrey 1974, 1997, Pastoureaud et al. 1995, Loret et al. 2000, Louda et al. 2008, Sanz et al. 2015 for pigments; Parrish et al. 1995, Soudant et al. 1996, Bachok et al. 2003, 2009 for FAs; and Volkman 1986, Napolitano et al. 1993, Soudant et al. 1998a for sterols). These biomarkers have been extensively used in foraging ecology and food web studies. Statistical methods are in development to assess the contribution of different food sources in the diet, e.g. CHEMTAX for pigments (Mackey et al. 1996) and for FA analysis (Dijkman \& Kromkamp 2006) or quantitative fatty acid signature analysis (QFASA) in FA studies (Iverson et al. 2004). However, their distribution is complex, with few unambiguous biomarkers. It is therefore important that other techniques are used to identify the food types present (Wright \& Jeffrey 2006). In this context, combining pigment and lipid compositions of tissues could prove advantageous to assess seasonal variability of food sources (Hurtado et al. 2012).

The present study describes the temporal qualitative and quantitative variations in trophic sources consumed by P. maximus, in an innovative approach combining 3 well established trophic markers: pigments, FAs and sterols, in the digestive gland and rectum contents. The coupling of these 3 biomarkers is expected to provide a full understanding of both high-frequency and long-term patterns in the feeding ecology of the great scallop and to help trace different food sources from various origins. 


\section{Material and methods}

\subsection{Study area and sampling protocol}

The study was conducted in the Bay of Brest (Brittany, France). Pecten maximus were dredged in the bay in November 2010 and then relocated to Lanvéoc (48 $17^{\prime} \mathrm{N}, 4^{\circ} 27^{\prime} \mathrm{W}$, average depth: $12 \mathrm{~m}$ ). From 14 March 2011 until 24 October 2011, 3 individuals were collected by SCUBA divers every 2 wk. During April and May, corresponding to a period of high phytoplankton productivity, scallops were sampled twice a week. Only animals over 3 yr old (identified by yearly shell growth rings; Mason 1957), and thus fully mature, were selected for this study. The digestive gland (DG) content, hereafter referred to as the stomach content, was collected in $2 \mathrm{ml}$ Eppendorf tubes by squeezing the DG. In the same way, the content of the posterior part of the intestine (branch outside the gonad) was obtained by pressing the rectum. Stomach fraction was used as a proxy of ingested food, and rectum fraction was considered as the digested part of food that was not assimilated. A total of 2 aliquots of DG tissue were encapsulated into aluminium cups. DG content and tissue samples were frozen in liquid nitrogen and stored at $-80^{\circ} \mathrm{C}$ until sample treatment.

Seawater was also sampled using a $5 \mathrm{I}$ Niskin bottle at $2 \mathrm{~m}$ below the surface during the entire study period. Sampling of the water-sediment interface was carried out by SCUBA divers from early May, using a $450 \mathrm{ml}$ syringe to collect water at approximately $3 \mathrm{~cm}$ above the sea bottom. Sampling was performed as far as possible at medium tidal coefficient and around mid-tide. Phytoplankton species composition and abundance were determined in samples both in the water column and at the water-sediment interface. A volume of $250 \mathrm{ml}$ of each sample was fixed with acetic Lugol's solution. Quantitative and qualitative analyses were carried out from settled cells using an inverted phase microscope. Vacuum filtration of seawater was conducted on GF/F filters $(0.7 \mu \mathrm{m})$ previously heated for $6 \mathrm{~h}$ at $450^{\circ} \mathrm{C}$. Between $500 \mathrm{ml}$ and $1.5 \mathrm{I}$ of sub-surface seawater were filtered at each sampling time. The volume of filtered bottom water ranged from 50 to $150 \mathrm{ml}$, depending on filter clogging. Two filtrations were carried out for water column samples and 2 for water-sediment interface samples, for pigment and lipid analysis. Filtrates were stored in sealed aluminium folds at $-80^{\circ} \mathrm{C}$ until sample treatment. Simultaneous analyses of pigment composition of the seston from the water column and from the water-sediment interface were conducted whenever possible as they were not available for the first 2 mo of the study. Nevertheless, the occurrence, timing and intensity of spring phytoplankton at the bottom were well documented in a study carried out at the same time and the same location (Chatterjee et al. 2013). Pigment and lipid composition of all samples (DG content, DG tissue of scallops and filtrates) were analyzed as described below.

\subsection{Pigment analysis}

The procedure used to identify and quantify pigments in the filters and in the DG contents was the method described by Claustre \& Ras (2009). The extraction of pigments was achieved from $200 \mu$ of stomach contents, $50 \mu \mathrm{g}$ of rectum contents and seawater filtrates from the 2 depths, in $100 \%$ methanol enriched with vitamin E acetate (used as internal standard; Sigma-Aldrich). To improve extraction yield, samples were disrupted by sonication using an S-4000 sonicator (Misonix) and stored at $-20^{\circ} \mathrm{C}$. 
Sonication was repeated after 2 and $4 \mathrm{~h}$ of extraction. Samples were centrifuged for $10 \mathrm{~min}$ at $3000 \mathrm{rpm}$ $\left(805 \times \mathrm{g} ; 4^{\circ} \mathrm{C}\right.$ ) and passed through $13 \mathrm{~mm}$ syringe filters (Puradisc, $0.2 \mu \mathrm{m}$, PTFE; Fischer). Pigment analyses were carried out on a complete Agilent Technologies 1200 series HPLC system, equipped with a ZORBAX Eclipse XDB-C8 silica column ( $3 \times 150 \mathrm{~mm}, 3.5 \mathrm{~mm}$ particle size) and a diode array detector, which permits automatic pigment identification based on absorption spectra. The elution was run at a flow rate of $0.55 \mathrm{ml} \mathrm{min}^{-1}$ using solvent $A$ (tetrabutylammonium acetate and methanol, 30:70 v/v) and solvent $B$ (methanol) in the following elution procedure (min, solv. A, solv. B): $(0,90,10),(22,5,95),(27$, $5,95),(28,90,10)$ and $(33,90,10)$. Pigment optical densities were monitored at $450 \mathrm{~nm}$ (chloropigments and carotenoids) and at $667 \mathrm{~nm}$ (chlorophyll $a$ [chl $a$ ] and derived pigments), and automatically compared to the retention times of 15 pigment standards (DHI and Sigma-Aldrich) previously calibrated. The injection precision of the method was estimated at $0.4 \%$, and the effective limits of quantification for most pigments were rather low: $2.8910^{-5} \mathrm{\mu g} \mathrm{ml}^{-1}$ for chl $a$ and $3.9810^{-5} \mu \mathrm{g}$ $\mathrm{ml}^{-1}$ for carotenoids. Chemstation software was used for verification and eventual correction of the peak integrations in each chromatogram.

\subsection{Lipid analysis}

\subsubsection{Chemicals}

HPLC-grade solvents were purchased from VWR International. Boron trifluoride (BF3; $14 \%$ by weight in methanol), tricosanoic acid (C23:0), cholestane and 37-component fatty acid methyl ester (FAME) mix were obtained from Sigma-Aldrich. Silica gel 60 (63-230 $\mu \mathrm{m}$ mesh) was purchased from Merck. Gas chromatography (GC) capillary column was a DBWAX (30 $\mathrm{m} \times 0.25 \mathrm{~mm}$ i.d., $0.25 \mu \mathrm{m}$ thickness) for FAME analysis and a Rtx65 ( $15 \mathrm{~m} \times 0.25 \mathrm{~mm}$ i.d., $0.25 \mu \mathrm{m}$ thickness) for sterol analysis and were obtained from Agilent and Restek, respectively.

\subsubsection{Lipid extraction}

Lipid extraction was conducted by resuspension of the filtrates or of $200 \mathrm{mg}$ aliquots of DG previously grounded by ball milling under liquid nitrogen. Samples were then put in glass tubes containing $6 \mathrm{ml}$ of chloroform-methanol $(2: 1, \mathrm{v} / \mathrm{v})$ and stored at $-20^{\circ} \mathrm{C}$ before analysis.

\subsubsection{Separation}

After centrifugation ( $2 \mathrm{~min}, 1000 \mathrm{rpm}$ ), lipid analyses were carried out on $1 \mathrm{ml}$ of DG lipid extracts and on $5 \mathrm{ml}$ of filtrate lipid extracts (due to the small amount of material in the seawater when compared to the DG). Lipid extracts were then evaporated to dryness under nitrogen, recovered with 3 chloroformmethanol $(98: 2, \mathrm{v} / \mathrm{v})$ washings of $500 \mu \mathrm{l}$ each and deposited at the top of a silica gel microcolumn (Pasteur pipette of $5 \mathrm{~mm}$ i.d., plugged with glass wool and filled with silica gel 60, both previously heated for $6 \mathrm{~h}$ at $450^{\circ} \mathrm{C}$ and deactivated with $6 \%$ water by weight). Neutral lipids (NL), including triglycerides, free FAs and sterols, were eluted with $10 \mathrm{ml}$ of chloroform-methanol $(98: 2 \mathrm{v} / \mathrm{v})$ and polar lipids (PL), containing glycolipids and phospholipids, were eluted with $20 \mathrm{ml}$ of methanol; both were collected in $20 \mathrm{ml}$ vials. 


\subsubsection{Transesterification}

After evaporation to dryness under nitrogen, PL and NL fractions were recovered and transferred in $8 \mathrm{ml}$ vials with 3 chloroform-methanol $(98: 2, \mathrm{v} / \mathrm{v})$ washings of $1 \mathrm{ml}$ each. The $\mathrm{NL}$ fraction was then equally divided into 2 vials. All of the PL fraction and half of NL fraction were dedicated to FA analysis; the other part of the NL fraction was dedicated to sterol analysis. As internal standards, 2.3 $\mu \mathrm{g}$ of C23:0 was added to the FA vials and $2.5 \mu \mathrm{g}$ of cholestane to the sterols vials. After evaporation to dryness under nitrogen, FAMEs were obtained by adding $800 \mu \mathrm{l}$ of methanol-BF3 to FA vials, vortexing and heating for $10 \mathrm{~min}$ at $100^{\circ} \mathrm{C}$. For sterol analysis, $2 \mathrm{ml}$ of a sodium methoxyde solution $\left(\mathrm{NaOH}, 27 \mu \mathrm{g} \mathrm{l}^{-1}\right.$ in methanol) was added to the sterol vials, which were maintained under agitation for $90 \mathrm{~min}$ at room temperature. Before GC analysis, organic phases containing FAME or sterols were washed 3 times with $1 \mathrm{ml}$ of distilled water and $800 \mu \mathrm{l}$ of hexane and centrifuged $(1 \mathrm{~min}$ at $1000 \mathrm{rpm}$ ) before eliminating the aqueous phase each time. Finally, organic phases were transferred into tapering vials and stored at $-20^{\circ} \mathrm{C}$.

\subsubsection{GC analysis}

FAMEs were analyzed in an Agilent 6890 gas chromatograph equipped with an on-column injector and a flame-ionization detector, with hydrogen as a carrier gas. They were identified by their retention times with reference to those of a standard 37-component FAME mix and other known standard mixtures from marine bivalves (Soudant et al. 1995) and designated following the formula C:X(n-Y) where $C$ is the number of carbon atoms, $X$ is the number of double bonds and $Y$ is the position of the first double bond counted from the $\mathrm{CH}$ terminal. The sterols were separated by GC, in a Chrompack 9002 equipped with an on-column injector and a flame-ionization detector, with hydrogen as a carrier gas. Sterols were identified by comparison of their retention time with standards as described in Soudant et al. (1998a).

\subsection{Data analysis}

As chl $a$ is present in all marine algae species and because the goal of this study was to identify specific patterns in the dynamics of several algae classes, chl $a$ was removed from the total amount of pigments; each pigment quantity was therefore expressed as its contribution to the total amount of pigment without chl $a$. This was applied to all samples (seawater and digestive tract contents).

Statistical analyses were carried out to determine significant temporal variations in the different food proxies, analyzed using R v.3.3.2 (R Core Team 2013). Potential correlations between pigment concentrations in the 2 water compartments and the stomach contents were investigated through simple linear regressions. A canonical correspondence analysis (CCA) integrating all food proxy variables in the environment (phytoplankton counts and pigments in the water column and at the water-sediment interface) and the proportion of pigments, FAs and sterols in the stomach contents over time was performed using the package 'vegan' (Oksanen et al. 2017). Degraded pigments (pheophytin and pheophorbide) as well as pigments, FAs and sterols whose proportions averaged less than $0.5 \%$ were excluded. Because no water samples were available at the water-sediment interface until May, the CCA was performed for sampling points after 2 May. First trials included all variables at the same time, and were not successful in identifying clear relationships, likely due to the elevated number of variables. Therefore 2 separate analyses were performed, both using phytoplankton counts 
as variables and time series of pigment proportions in the water and the stomach contents or lipid proportions in the DG tissues.

\section{Results}

\subsection{Seston pigment concentration and composition}

A general pattern of phytoplankton abundance during the study period can be seen in Fig. 1, showing the dynamics of chl a concentration in the seston from the water column as well as at the water-sediment interface. The first sign of primary production recovery after winter in the water column occurred at the end of March, but the first significant phytoplankton bloom was observed at the water-sediment interface in mid-April. Microalgae grew in the water column in early May. In June, another bloom occurred in the water column while pigment concentrations in the bottom water de creased. During the summer, few blooms were recorded in the water column, while low pigment amounts were found at the bottom. In autumn, phytoplankton biomass increased in both water compartments. Pigment concentration in the water column seemed to decline rapidly in August, while bottom production reached high levels in September, comparable to those observed in spring.

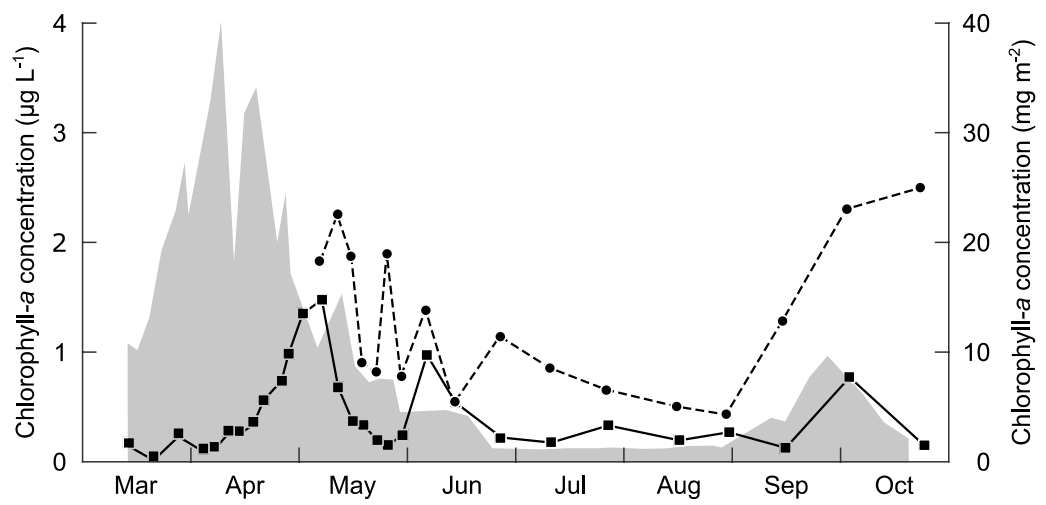

Fig. 1. Chl $a$ concentration in the water column (solid line, black squares) and in the water-sediment interface (dashed line, black dots) in the Bay of Brest, France, in 2011. Additional data for chl $a$ concentration (grey area, right axis) at the sea floor are from Chatterjee et al. (2013)

Detailed phytoplankton composition in the water column and the water-sediment interface are presented in Table 1. Although identification has been performed to species level, data are presented by microalgae classes. The water from the sea bottom was mainly composed of diatoms (Bacillariophyceae), of which the highest abundance was recorded in early March. In the water column, the first observed bloom occurred in late March and was mainly composed of Dinophyceae and Cryptophyceae, with 276800 and 2810000 cells I $^{-1}$ respectively (mostly Heterocapsa triquetra and Gyrodinium flagellare). A synchronous elevation of alloxanthin and peridinin was observed in the water column (Fig. 2b,e). The pigment composition of seston in late April showed increasing proportions of $19^{\prime}$-hexanoyloxyfucoxanthin (19'HF) and 19'-butanoyloxy-fucoxanthine (19'BF), up to 15 and $10 \%$ respectively in the water column (Fig. $2 d, f$ ). At the same time, the highest abundances of 
Prymnesiophyceae and Chrysophyceae were recorded (Table 1). Diatoms were highly abundant from the beginning but showed a surge in early May (mostly Chaetoceros sp., Cerataulina pelagica and Dactiliosolen fragilissima in the water column, and Navicula sp. and Fragillaria sp. at the water-sediment interface), accompanied by peaks of fucoxanthin in both water compartments (Fig. 2a), contributing $\mathbf{7 7 \%}$ of the total pigments. Almost all pigment proportions increased during this bloom, except for peridinin, which only showed several short peaks (around $10 \%$ of the total pigment) during the study period. The second major microalgae bloom was mostly due to diatoms, and occurred in early June with up to 2747400 cells I $^{-1}$. A sharp increase of fucoxanthin concentration was again observed in the water. From then on, fucoxanthin concentrations remained at lower levels both in the water column and at the water-sediment interface, whereas the proportion of chlorophyll $b$ (chl $b$ ) started to increase from about $10 \%$ to more than $20 \%$ in the water column in June (Fig. 2e). During this period, only trace amounts of green microalgae (Chlorophyceae) were observed. The same occurred at the bottom from July, also accompanied by a similar increase of peridinin and zeaxanthin concentrations. Alloxanthin and $19^{\prime} \mathrm{HF}$ accounted for about 5\% of the total pigments from mid-summer until the end of the study. High numbers of Cryptophyceae and Prymnesiophyceae were observed during these last months. Finally, in October, a last bloom of diatoms was recorded at the water-sediment interface while seston pigment composition was dominated by fucoxanthin (up to $40 \%$ ) and chl $b(50 \%)$. Degradation pigments such as pheophorbide- $a$ and pheophytin- $a$ were detected at very low amounts in the water during the whole study period. Other pigments were detected in this study (probably degraded forms of the main pigments already described) but were not taken into account as we did not have the specific standards for their identification at our disposal.

Table 1. Phytoplankton composition of the water column ( $2 \mathrm{~m}$ under the surface) and at the water-sediment interface $(3 \mathrm{~cm}$ above bottom) in the Bay of Brest in 2011 (in no. of cells ${ }^{-1}$ ) (table continued on next page)

\begin{tabular}{lrrrrrrr}
\hline $\begin{array}{c}\text { Date } \\
\text { (dd/mo) }\end{array}$ & $\begin{array}{c}\text { Bacillario- } \\
\text { phyceae }\end{array}$ & $\begin{array}{c}\text { Dino- } \\
\text { phyceae }\end{array}$ & $\begin{array}{c}\text { Chloro- } \\
\text { phyceae }\end{array}$ & $\begin{array}{c}\text { Chryso- } \\
\text { phyceae }\end{array}$ & $\begin{array}{c}\text { Crypto- } \\
\text { phyceae }\end{array}$ & $\begin{array}{c}\text { Cyano- } \\
\text { phyceae }\end{array}$ & $\begin{array}{c}\text { Prymnesio- } \\
\text { phyceae }\end{array}$ \\
\hline Water column & & & & & & & \\
$10 / 03$ & 26950 & 23300 & 0 & 0 & 0 & 0 & 25750 \\
$17 / 03$ & 21260 & 53130 & 0 & 5000 & 236100 & 0 & 2500 \\
$25 / 03$ & 11370 & 276800 & 0 & 0 & 2810000 & 0 & 16100 \\
$31 / 03$ & 138635 & 24920 & 0 & 2700 & 122000 & 0 & 0 \\
$08 / 04$ & 184940 & 35740 & 0 & 0 & 171000 & 0 & 600 \\
$14 / 04$ & 17630 & 18750 & 0 & 16900 & 143200 & 0 & 15800 \\
$23 / 04$ & 116560 & 115060 & 0 & 12050 & 211000 & 0 & 91530 \\
$29 / 04$ & 601820 & 48960 & 0 & 75400 & 27630 & 0 & 32950 \\
$05 / 05$ & 956290 & 54800 & 7780 & 9540 & 105500 & 0 & 47480 \\
$13 / 05$ & 640910 & 76891 & 0 & 0 & 291060 & 0 & 0 \\
$23 / 05$ & 7225 & 124000 & 47730 & 2500 & 445450 & 0 & 7500 \\
$30 / 05$ & 91220 & 10330 & 0 & 0 & 13190 & 0 & 0 \\
$06 / 06$ & 2747400 & 32780 & 0 & 0 & 55260 & 0 & 13190 \\
$13 / 06$ & 232060 & 86780 & 0 & 4900 & 82900 & 0 & 0 \\
$21 / 06$ & 28230 & 46120 & 0 & 1900 & 231100 & 0 & 5200 \\
$30 / 06$ & 789730 & 55720 & 9100 & 1000 & 226080 & 0 & 40250 \\
$08 / 07$ & 126310 & 18810 & 0 & 0 & 30140 & 0 & 15500 \\
$12 / 07$ & 627150 & 79980 & 0 & 0 & 105500 & 2080 & 12560 \\
$21 / 07$ & 19120 & 90930 & 0 & 0 & 288900 & 0 & 12640 \\
$28 / 07$ & 158690 & 4590 & 0 & 0 & 37680 & 0 & 0
\end{tabular}




\begin{tabular}{|c|c|c|c|c|c|c|c|}
\hline $\begin{array}{c}\text { Date } \\
\text { (dd/mo) }\end{array}$ & $\begin{array}{l}\text { Bacillario- } \\
\text { phyceae }\end{array}$ & $\begin{array}{c}\text { Dino- } \\
\text { phyceae }\end{array}$ & $\begin{array}{l}\text { Chloro- } \\
\text { phyceae }\end{array}$ & $\begin{array}{l}\text { Chryso- } \\
\text { phyceae }\end{array}$ & $\begin{array}{l}\text { Crypto- } \\
\text { phyceae }\end{array}$ & $\begin{array}{l}\text { Cyano- } \\
\text { phyceae }\end{array}$ & $\begin{array}{c}\text { Prymnesio- } \\
\text { phyceae }\end{array}$ \\
\hline $06 / 08$ & 170770 & 38860 & 0 & 0 & 145700 & 0 & 21700 \\
\hline $11 / 08$ & 23520 & 76810 & 0 & 0 & 158260 & 0 & 0 \\
\hline $19 / 08$ & 18920 & 52860 & 0 & 0 & 384340 & 0 & 1000 \\
\hline $26 / 08$ & 221600 & 6360 & 0 & 0 & 60290 & 0 & 0 \\
\hline $04 / 09$ & 1520 & 200 & 0 & 0 & 11000 & 0 & 0 \\
\hline $10 / 09$ & 5140 & 23540 & 0 & 0 & 263760 & 0 & 0 \\
\hline $16 / 09$ & 7840 & 36700 & 0 & 0 & 146850 & 0 & 4500 \\
\hline $24 / 09$ & 137700 & 15460 & 0 & 0 & 133140 & 0 & 0 \\
\hline $03 / 10$ & 155300 & 95730 & 0 & 5000 & 562690 & 0 & 55260 \\
\hline $10 / 10$ & 30400 & 63880 & 0 & 4340 & 183270 & 0 & 14100 \\
\hline $17 / 10$ & 1000 & 34280 & 0 & 0 & 450210 & 0 & 67960 \\
\hline $23 / 10$ & 1160 & 7820 & 0 & 0 & 77870 & 0 & 15070 \\
\hline \multicolumn{8}{|c|}{ Water-sediment interface } \\
\hline $10 / 03$ & 3042490 & 0 & 0 & 0 & 0 & 0 & 0 \\
\hline $21 / 03$ & 0 & 40 & 0 & 0 & 0 & 0 & 0 \\
\hline $24 / 03$ & 1080 & 0 & 0 & 2100 & 75500 & 0 & 0 \\
\hline $28 / 03$ & 127110 & 20 & 0 & 0 & 0 & 0 & 0 \\
\hline $31 / 03$ & 63540 & 240 & 0 & 0 & 10100 & 0 & 0 \\
\hline 04/04 & 59190 & 280 & 0 & 0 & 4050 & 0 & 0 \\
\hline 07/04 & 23520 & 0 & 0 & 0 & 4000 & 0 & 0 \\
\hline $11 / 04$ & 124140 & 4110 & 0 & 0 & 8050 & 0 & 0 \\
\hline $14 / 04$ & 19170 & 80 & 0 & 0 & 0 & 0 & 0 \\
\hline $18 / 04$ & 74760 & 120 & 0 & 0 & 1000 & 0 & 0 \\
\hline $21 / 04$ & 113050 & 20500 & 0 & 4000 & 217510 & 0 & 0 \\
\hline $26 / 04$ & 34910 & 2280 & 0 & 0 & 12100 & 0 & 0 \\
\hline $28 / 04$ & 89860 & 40 & 0 & 0 & 33720 & 0 & 0 \\
\hline $02 / 05$ & 75400 & 600 & 0 & 0 & 0 & 0 & 0 \\
\hline $09 / 05$ & 301860 & 600 & 0 & 0 & 0 & 0 & 0 \\
\hline $12 / 05$ & 176870 & 1240 & 0 & 0 & 0 & 0 & 0 \\
\hline $16 / 05$ & 250460 & 12780 & 0 & 0 & 16900 & 0 & 0 \\
\hline $19 / 05$ & 1760 & 400 & 0 & 0 & 0 & 0 & 0 \\
\hline $23 / 05$ & 69020 & 800 & 0 & 0 & 2000 & 0 & 0 \\
\hline $26 / 05$ & 600 & 2100 & 0 & 0 & 0 & 0 & 0 \\
\hline $30 / 05$ & 76085 & 1280 & 0 & 0 & 0 & 0 & 0 \\
\hline $06 / 06$ & 720 & 1280 & 0 & 0 & 0 & 0 & 0 \\
\hline $14 / 06$ & 40 & 2280 & 0 & 0 & 1000 & 0 & 0 \\
\hline $20 / 06$ & 23460 & 10300 & 0 & 0 & 10100 & 0 & 0 \\
\hline $27 / 06$ & 180 & 20 & 0 & 0 & 500 & 0 & 0 \\
\hline $19 / 07$ & 0 & 0 & 0 & 0 & 0 & 0 & 0 \\
\hline $27 / 07$ & 0 & 0 & 0 & 0 & 0 & 0 & 0 \\
\hline $01 / 08$ & 3120 & 40 & 0 & 0 & 0 & 0 & 0 \\
\hline $09 / 08$ & 5800 & 100 & 0 & 0 & 0 & 0 & 0 \\
\hline $16 / 08$ & 3480 & 440 & 0 & 0 & 12100 & 0 & 0 \\
\hline $22 / 08$ & 9600 & 200 & 0 & 0 & 0 & 0 & 0 \\
\hline $30 / 08$ & 61500 & 0 & 0 & 0 & 0 & 0 & 0 \\
\hline 05/09 & 2800 & 0 & 0 & 0 & 0 & 0 & 0 \\
\hline $13 / 09$ & 2000 & 0 & 0 & 0 & 0 & 0 & 0 \\
\hline $19 / 09$ & 57550 & 0 & 0 & 90630 & 0 & 0 & 0 \\
\hline $26 / 09$ & 49060 & 0 & 0 & 20130 & 0 & 0 & 0 \\
\hline $03 / 10$ & 51620 & 6040 & 0 & 20140 & 10000 & 0 & 0 \\
\hline $10 / 10$ & 889770 & 3200 & 2000 & 6050 & 0 & 0 & 0 \\
\hline $17 / 10$ & 78410 & 4500 & 0 & 2000 & 0 & 0 & 0 \\
\hline $24 / 10$ & 2000 & 2000 & 0 & 0 & 0 & 0 & 0 \\
\hline
\end{tabular}




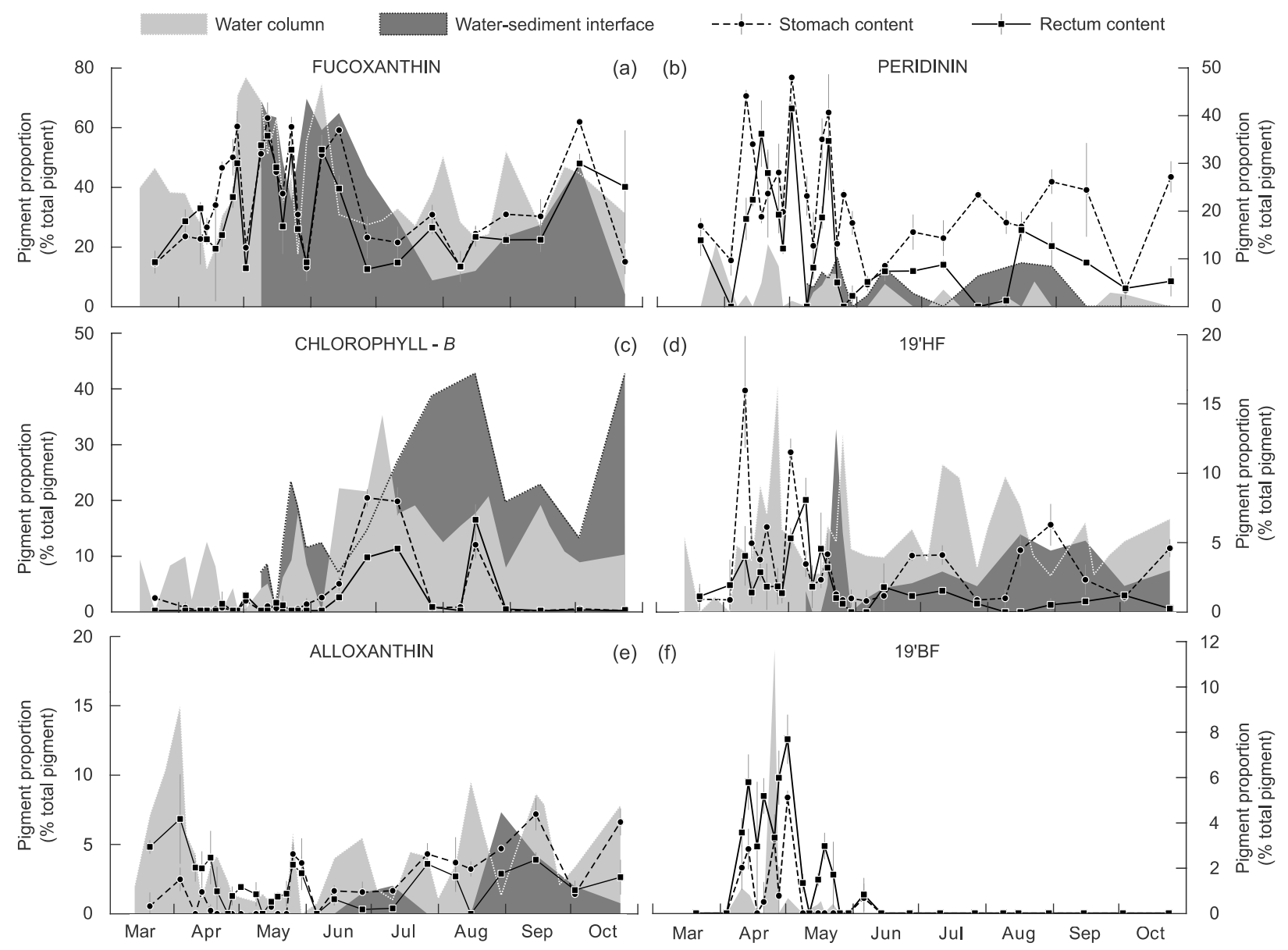

Fig. 2. Proportions of (a) fucoxanthin, (b) peridinin, (c) chl b, (d) 19'HF, (e) alloxanthin and (f) 19'BF in the water column (light grey area) and at the water-sediment interface (dark grey area) and in the stomach (dashed dark line, black dots) and the rectum content (solid dark line, black squares) of Pecten maximus in the Bay of Brest in 2011. Chl a quantity was removed from total pigment amount before calculating the proportion of each pigment. Standard deviations are indicated by vertical grey lines

\subsection{Pigment composition of the digestive tract contents}

Over the duration of the study, the quantity of pigments measured in the stomach content seemed to match the quantity found in the seston only during certain periods of the study (Fig. 3). This is reflected by a weak correlation between the pigment concentration in the stomach content and the pigment concentration in the seston from both the water column and the water-sediment interface $\left(r^{2}=\right.$ 0.3074 and $r^{2}=0.1322$ respectively; $p<0.01$ ) when considering the whole sampling period. However, these correlations are greatly improved when the time series is split into 2 periods (spring and summer/fall). A very strong correlation between the concentration in the stomach contents and in the water column was found from June until the end of the study $\left(r^{2}=0.9394, p<0.01\right)$. On the other hand, the correlation between the concentration in the stomach contents and in the water-sediment interface was stronger before June $\left(r^{2}=0.4943, p<0.01\right)$. 

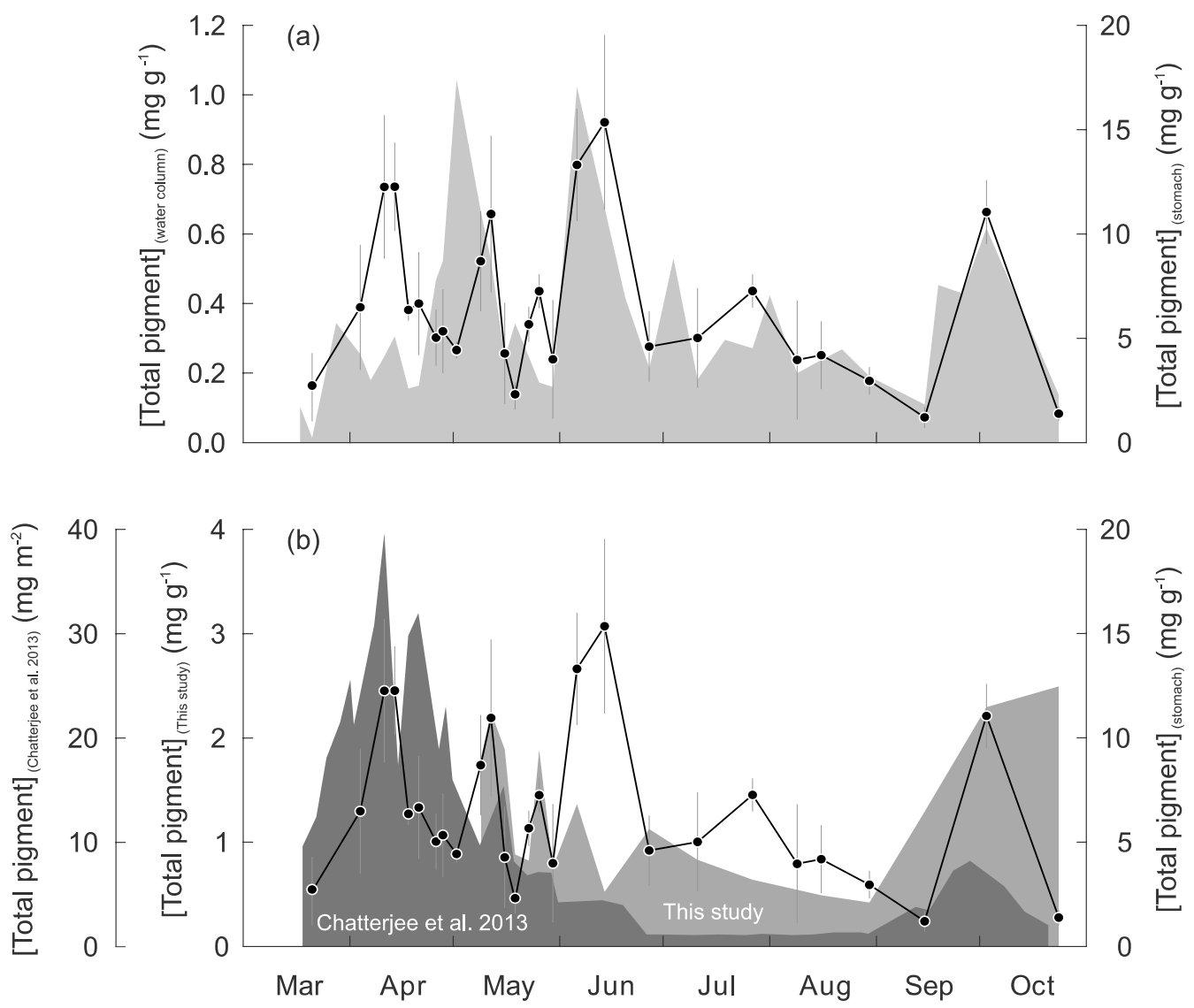

Fig. 3. (a,b) Total quantity of pigment, including chl $a$, measured in the stomach content of Pecten maximus (dark line in [a,b]), in the water column (light grey area in [a]), and at the water-sediment interface (grey area in [b]) in the Bay of Brest in 2011. Standard deviations are indicated by vertical grey lines. Data from the water-sediment interface from the study of Chatterjee et al. (2013) are also plotted (dark grey area in [b]) to complete the present data set

Fucoxanthin was, after $\mathrm{chl} a$, the major pigment found both in stomach and rectum (up to 55 and $50 \%$ respectively; Table 2). Peridinin had a maximum occurrence of $43 \%$ in the stomach and $28 \%$ in the rectum. The dynamics of these 2 predominant pigments varied in an opposite manner, as shown in Fig. 4. Fucoxanthin in the stomach fluctuated strongly during spring (Fig. 2a), with sharp increases from 10-20\% up to $50-55 \%$ in late April, mid-May, late May and early June. The minimum was observed on 30 May (11.4\%) and the maximum on 28 April at $53.6 \%$. As observed in the water, a significant increase was registered in autumn. The proportion of fucoxanthin in the rectum was very similar to what was observed in the stomach, as shown by a linear regression coefficient of $r^{2}=0.82(p<0.01)$. Peridinin showed a similar pattern, with a fluctuating spring period followed by low proportions in early summer and medium levels until autumn, when it dropped to its minimum (2.4\%) on 3 October. The maximum was reached on 2 May at 42.3\%. Compared to fucoxanthin, the linear regression between the proportion of peridinin in the rectum and in the stomach was less significant $\left(r^{2}=0.52, p<0.01\right)$. For instance, at the end of May as well as in July and August, the discrepancy between the two compartments was $20 \%$ between the entrance and the exit of the digestive tract (Fig. 2 b). 
Table 2. Pigments proportion expressed as pigment percentage of total in the stomach and the rectum of Pecten maximus in the Bay of Brest in 2011. Chl a quantity was removed from total pigment amount before calculating the proportion of each pigment. PHB: pheophorbide- $a$, PER: peridinin, BFU: 19'BF, FUC: fucoxanthin, HFU: 19'HF, ALO: alloxanthin, ZEA: zeaxanthin, LUT: lutein, CHB: chlorophyll- $b$, PHT: pheophytin- $a$. Standard deviations are in brackets

\begin{tabular}{|c|c|c|c|c|c|c|c|c|c|c|}
\hline Date $(\mathrm{dd} / \mathrm{mo})$ & PHB & PER & BFU & FUC & HFU & ALO & ZEA & LUT & $\mathrm{CHB}$ & PHT \\
\hline \multicolumn{11}{|l|}{ Stomach } \\
\hline $21 / 03$ & $18.7(4.6)$ & $16.9(1.6)$ & $0.0(0.0)$ & $14.4(1.4)$ & $0.9(0.8)$ & $0.7(1.2)$ & $2.7(1.6)$ & $1.5(0.7)$ & $2.3(0.3)$ & $27.1(3.3)$ \\
\hline $04 / 04$ & $31.1(7.2)$ & $9.7(3.1)$ & $0.0(0.0)$ & $23.6(0.8)$ & $0.9(1.5)$ & $3.1(1.0)$ & $0.0(0.0)$ & $0.0(0.1)$ & $0.5(0.9)$ & $23.1(6.3)$ \\
\hline $11 / 04$ & $0.0(0.0)$ & $44.1(1.2)$ & $2.0(1.0)$ & $22.7(8.4)$ & $16.0(4.5)$ & $0.0(0.0)$ & $0.0(0.0)$ & $0.0(0.0)$ & $0.0(0.0)$ & $0.0(0.0)$ \\
\hline $18 / 04$ & $7.9(1.1)$ & $18.8(1.3)$ & $0.0(0.0)$ & $34.0(0.4)$ & $3.8(0.4)$ & $0.3(0.5)$ & $0.0(0.1)$ & $0.1(0.2)$ & $0.3(0.5)$ & $28.9(1.3)$ \\
\hline $26 / 04$ & $5.2(1.1)$ & $28.1(5.9)$ & $3.2(0.5)$ & $50.1(6.0)$ & $1.7(0.6)$ & $0.0(0.0)$ & $0.0(0.0)$ & $0.0(0.0)$ & $0.0(0.0)$ & $5.1(1.6)$ \\
\hline $28 / 04$ & $0.0(0.0)$ & $19.8(5.4)$ & $0.7(1.3)$ & $60.4(5.0)$ & $1.3(0.3)$ & $0.0(0.0)$ & $0.0(0.0)$ & $0.0(0.0)$ & $0.0(0.0)$ & $9.1(0.9)$ \\
\hline $02 / 05$ & $0.0(0.0)$ & $48.0(0.1)$ & $5.1(0.3)$ & $19.8(2.2)$ & $11.5(1.0)$ & $0.0(0.0)$ & $0.0(0.0)$ & $0.0(0.0)$ & $1.8(1.8)$ & $0.2(0.3)$ \\
\hline $09 / 05$ & $0.0(0.5)$ & $25.6(4.1)$ & $0.0(0.0)$ & $56.6(4.5)$ & $3.8(0.9)$ & $0.0(0.0)$ & $0.0(0.0)$ & $0.0(0.0)$ & $0.0(0.0)$ & $4.2(1.2)$ \\
\hline $12 / 05$ & $0.0(0.9)$ & $13.3(6.9)$ & $0.0(0.0)$ & $66.0(5.0)$ & $2.0(0.7)$ & $0.0(0.0)$ & $0.1(0.1)$ & $0.0(0.0)$ & $0.8(0.8)$ & $1.8(1.7)$ \\
\hline $16 / 05$ & $0.0(0.0)$ & $35.0(4.3)$ & $0.0(0.0)$ & $45.1(3.1)$ & $2.3(0.6)$ & $0.6(0.1)$ & $0.0(0.0)$ & $0.0(0.0)$ & $0.4(0.7)$ & $3.9(0.5)$ \\
\hline $19 / 05$ & $0.0(0.0)$ & 40.7 (7.9) & $0.0(0.0)$ & $37.9(6.2)$ & $4.2(1.5)$ & $0.0(0.0)$ & $0.0(0.0)$ & $0.0(0.0)$ & $0.0(0.0)$ & $6.9(2.2)$ \\
\hline $23 / 05$ & $0.8(1.2)$ & $13.2(1.2)$ & $0.0(0.0)$ & $60.3(3.2)$ & $1.3(0.4)$ & $0.0(0.0)$ & $0.0(0.0)$ & $0.0(0.0)$ & $0.0(0.0)$ & $4.7(0.1)$ \\
\hline $26 / 05$ & $22.7(1.2)$ & $23.4(0.9)$ & $0.0(0.0)$ & $30.9(3.2)$ & $0.9(0.0)$ & $5.4(0.9)$ & $0.2(0.1)$ & $0.4(0.2)$ & $0.3(0.3)$ & $3.9(0.9)$ \\
\hline $30 / 05$ & $41.1(2.0)$ & $17.5(2.4)$ & $0.0(0.0)$ & $13.2(2.0)$ & $1.0(0.6)$ & $4.6(2.2)$ & $0.0(0.0)$ & $0.0(0.0)$ & $1.2(1.0)$ & $15.5(3.6)$ \\
\hline 06/06 & $0.0(0.0)$ & $4.6(1.3)$ & $0.7(0.6)$ & $50.9(3.4)$ & $0.8(0.8)$ & $0.0(0.0)$ & $0.0(0.0)$ & $0.4(0.4)$ & $2.4(0.6)$ & $26.0(6.7)$ \\
\hline $14 / 06$ & $2.4(2.5)$ & $8.5(0.3)$ & $0.0(0.0)$ & $59.2(2.4)$ & $1.2(1.1)$ & $2.1(0.5)$ & $0.0(0.0)$ & $0.1(0.1)$ & $4.9(1.2)$ & $5.7(1.7)$ \\
\hline $27 / 06$ & 5.7 (1.9) & $15.6(3.6)$ & $0.0(0.0)$ & $23.2(7.0)$ & $4.1(0.3)$ & $2.0(0.9)$ & $0.0(0.0)$ & $2.1(0.6)$ & $20.6(1.5)$ & $14.0(3.6)$ \\
\hline $11 / 07$ & $5.9(0.8)$ & $14.3(3.7)$ & $0.0(0.0)$ & $21.6(5.2)$ & $4.1(0.7)$ & $2.1(0.2)$ & $0.0(0.0)$ & $2.5(0.2)$ & $19.9(2.5)$ & $16.0(3.7)$ \\
\hline $27 / 07$ & $22.7(1.3)$ & $23.4(0.9)$ & $0.0(0.0)$ & $30.9(3.2)$ & $0.9(0.0)$ & $5.4(1.0)$ & $0.2(0.1)$ & $0.4(0.2)$ & $0.5(0.1)$ & $3.9(0.9)$ \\
\hline $16 / 08$ & $29.1(3.0)$ & $19.1(3.0)$ & $0.0(0.0)$ & $27.8(2.5)$ & $5.0(1.1)$ & $4.6(0.6)$ & $0.0(0.0)$ & $3.8(0.4)$ & $0.0(2.4)$ & $5.4(0.9)$ \\
\hline $30 / 08$ & $8.2(1.2)$ & $26.2(2.5)$ & $0.0(0.0)$ & $31.0(0.5)$ & $6.3(1.5)$ & $5.9(1.1)$ & $0.0(0.0)$ & $3.7(1.5)$ & $0.0(0.0)$ & $28.3(1.8)$ \\
\hline 05/09 & $10.2(9.5)$ & $24.4(9.7)$ & $0.0(0.0)$ & $30.3(5.7)$ & $2.3(1.1)$ & $9.0(1.4)$ & $0.0(0.0)$ & $4.3(0.3)$ & $0.0(0.0)$ & $5.8(5.1)$ \\
\hline $03 / 10$ & $4.3(2.6)$ & $3.4(1.8)$ & $0.0(0.0)$ & $62.0(1.1)$ & $1.1(0.4)$ & $1.8(0.2)$ & $0.1(0.0)$ & $0.0(0.1)$ & $0.3(0.6)$ & $9.5(4.4)$ \\
\hline $24 / 10$ & $18.7(1.2)$ & $27.2(3.2)$ & $0.0(0.0)$ & $15.1(4.0)$ & $4.6(0.6)$ & $8.3(1.2)$ & $0.0(0.0)$ & $0.3(0.0)$ & $0.0(0.0)$ & $6.0(0.2)$ \\
\hline \multicolumn{11}{|l|}{ Rectum } \\
\hline $21 / 03$ & $31.4(8.8)$ & $13.9(3.2)$ & $0.0(0.0)$ & $15.0(3.7)$ & $1.1(2.0)$ & $6.0(0.6)$ & $1.1(0.4)$ & $1.2(0.8)$ & $0.0(0.0)$ & $14.2(0.8)$ \\
\hline $04 / 04$ & $31.1(8.1)$ & $0.0(0.0)$ & $0.0(0.0)$ & $28.7(3.8)$ & $1.9(3.4)$ & $8.6(4.0)$ & $0.4(0.2)$ & $0.6(0.3)$ & $0.0(0.0)$ & 11.0 (1.9) \\
\hline $11 / 04$ & $6.5(2.1)$ & $18.4(4.4)$ & $3.6(0.6)$ & $33.0(2.0)$ & $4.0(2.1)$ & $4.2(1.2)$ & $0.0(0.0)$ & $0.0(0.0)$ & $0.0(0.0)$ & $10.8(0.8)$ \\
\hline $18 / 04$ & $0.0(0.0)$ & $36.2(6.9)$ & $2.9(2.8)$ & $19.5(17.5)$ & $2.9(0.6)$ & $5.1(2.4)$ & $0.3(0.3)$ & $1.4(0.8)$ & $0.0(0.0)$ & $7.9(7.7)$ \\
\hline $26 / 04$ & $15.5(1.4)$ & $19.3(3.8)$ & $3.3(1.0)$ & $36.8(3.5)$ & $1.9(1.3)$ & $0.0(0.0)$ & $0.2(0.2)$ & $0.1(0.2)$ & $0.0(0.0)$ & $6.4(0.8)$ \\
\hline $28 / 04$ & $0.0(0.0)$ & $12.1(1.0)$ & $6.0(1.2)$ & $48.1(5.3)$ & $1.4(0.7)$ & $1.6(0.8)$ & $0.1(0.1)$ & $0.1(0.1)$ & $0.0(0.0)$ & $17.0(5.2)$ \\
\hline $02 / 05$ & $1.5(0.4)$ & $41.5(1.8)$ & $7.7(1.1)$ & $12.9(0.9)$ & $5.3(0.7)$ & $2.4(0.2)$ & $0.4(0.1)$ & $0.4(0.1)$ & $2.8(0.4)$ & $4.6(0.7)$ \\
\hline 09/05 & $12.4(5.2)$ & $0.0(0.0)$ & $1.3(0.4)$ & $54.1(0.9)$ & $8.1(1.6)$ & $1.8(1.0)$ & $0.0(0.0)$ & $0.0(0.0)$ & $0.0(0.0)$ & 11.5 (1.9) \\
\hline $12 / 05$ & $7.8(1.8)$ & $8.1(1.1)$ & $0.0(0.0)$ & $57.3(0.9)$ & $1.8(1.5)$ & $0.0(0.0)$ & $0.2(0.1)$ & $0.1(0.1)$ & $0.0(0.0)$ & $6.6(0.8)$ \\
\hline $16 / 05$ & 4.2 (1.9) & $18.7(2.3)$ & $1.5(0.3)$ & $46.7(2.4)$ & $4.6(2.6)$ & $1.1(0.2)$ & $0.2(0.1)$ & $0.1(0.1)$ & $1.4(1.3)$ & $7.8(1.4)$ \\
\hline $19 / 05$ & $6.5(4.9)$ & $34.7(10.2)$ & $3.0(0.6)$ & $26.9(9.1)$ & $3.2(0.1)$ & $1.6(0.1)$ & $0.2(0.0)$ & $0.1(0.0)$ & $1.0(1.7)$ & $6.6(0.6)$ \\
\hline $23 / 05$ & $3.3(1.2)$ & $5.1(1.4)$ & $1.7(1.4)$ & $52.6(8.4)$ & $1.0(0.4)$ & $1.8(1.1)$ & $0.1(0.1)$ & $0.1(0.1)$ & $0.0(0.0)$ & $20.1(4.2)$ \\
\hline $26 / 05$ & $35.5(4.4)$ & $0.0(0.0)$ & $0.0(0.0)$ & $26.1(1.8)$ & $0.6(0.2)$ & $4.4(0.3)$ & $0.2(0.2)$ & $0.3(0.3)$ & $0.0(0.0)$ & $15.5(2.6)$ \\
\hline $30 / 05$ & $50.5(8.9)$ & $2.3(2.1)$ & $0.0(0.0)$ & $14.9(6.2)$ & $0.0(0.0)$ & $3.7(1.5)$ & $0.1(0.2)$ & $0.2(0.4)$ & $0.0(0.0)$ & $14.8(1.3)$ \\
\hline $06 / 06$ & $0.0(0.0)$ & $5.2(1.2)$ & $0.8(0.7)$ & $52.6(4.8)$ & $0.0(0.0)$ & $0.0(0.0)$ & $0.0(0.0)$ & $0.0(0.0)$ & $0.0(0.0)$ & $26.6(5.8)$ \\
\hline $14 / 06$ & $6.6(1.6)$ & 7.4 (1.9) & $0.0(0.0)$ & $39.6(4.2)$ & $1.8(1.7)$ & $1.3(0.5)$ & $0.0(0.0)$ & $0.7(0.1)$ & $2.4(0.8)$ & $20.2(3.4)$ \\
\hline $27 / 06$ & $9.8(0.9)$ & $7.4(0.6)$ & $0.0(0.0)$ & $12.6(0.8)$ & $1.2(0.1)$ & $0.4(0.1)$ & $0.0(0.0)$ & $7.9(1.3)$ & $9.7(0.5)$ & $19.7(2.8)$ \\
\hline $11 / 07$ & $11.7(0.6)$ & $8.8(0.8)$ & $0.0(0.0)$ & $14.8(1.4)$ & $1.5(0.3)$ & $0.5(0.1)$ & $0.0(0.0)$ & $9.2(1.6)$ & $11.3(0.5)$ & $21.6(3.8)$ \\
\hline $27 / 07$ & 33.9 (3.8) & $0.0(0.0)$ & $0.0(0.0)$ & $26.5(2.1)$ & $0.6(0.2)$ & $4.5(0.2)$ & $0.2(0.2)$ & $0.3(0.3)$ & $0.7(0.6)$ & $15.7(2.2)$ \\
\hline $16 / 08$ & $0.0(0.0)$ & $16.0(2.1)$ & $0.0(0.0)$ & $23.5(3.2)$ & $0.0(0.0)$ & $0.0(0.0)$ & $3.0(1.4)$ & $10.2(1.7)$ & $16.6(2.7)$ & $9.3(0.5)$ \\
\hline $30 / 08$ & $22.5(7.3)$ & $12.7(5.0)$ & $0.0(0.0)$ & $22.4(2.1)$ & $0.5(0.5)$ & $3.6(3.2)$ & $2.9(2.2)$ & $1.1(0.2)$ & $0.3(0.4)$ & $9.2(2.8)$ \\
\hline 05/09 & $20.2(8.5)$ & $9.2(0.3)$ & $0.0(0.0)$ & $22.5(4.0)$ & $0.8(0.1)$ & $4.9(0.6)$ & $1.6(0.1)$ & $1.2(0.4)$ & $0.0(0.0)$ & $19.1(1.5)$ \\
\hline $03 / 10$ & $10.4(4.0)$ & $3.8(0.6)$ & $0.0(0.0)$ & $48.0(3.1)$ & $1.2(0.0)$ & $2.1(0.8)$ & $0.2(0.3)$ & $0.1(0.2)$ & $0.1(0.1)$ & $14.7(3.2)$ \\
\hline $24 / 10$ & $10.1(4.8)$ & $5.3(3.1)$ & $0.0(0.0)$ & $40.2(18.8)$ & $0.2(0.1)$ & $3.3(1.5)$ & $0.0(0.0)$ & $0.0(0.0)$ & $0.0(0.0)$ & $5.9(2.9)$ \\
\hline
\end{tabular}




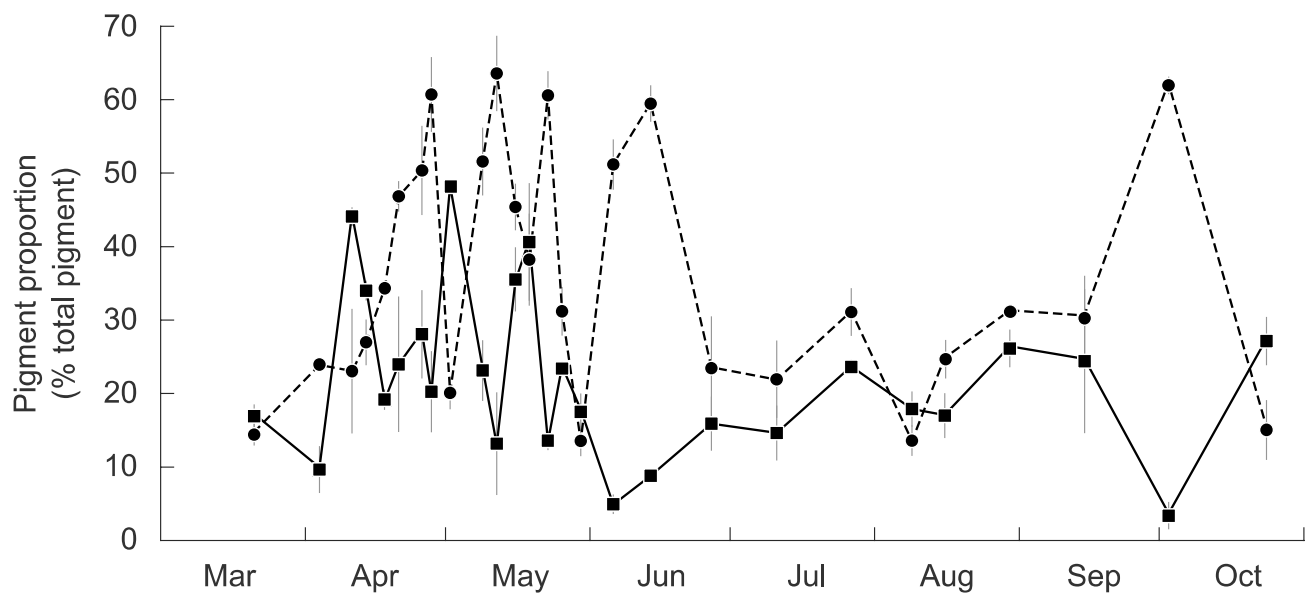

Fig. 4. Proportions of fucoxanthin (dots, dashed line) and peridinin (squares, solid line) in the stomach content of Pecten maximus in the Bay of Brest in 2011. Chl a quantity was removed from total pigment amount before calculating the proportion of each other pigment. Standard deviations are indicated by vertical grey lines

The occurrence of chl $b$ was not observed in the digestive tract of the scallops before an important peak of $13.5 \%$ during June and July and a shorter one in mid-August (12\%; Fig. 2c). In the rectum, proportions of $\mathrm{chl} b$ were found to be lower during the first increase (10.5\%) and higher during the second peak (16\%). Nevertheless, the correlation between the 2 compartments was rather elevated $\left(r^{2}=0.76\right)$. Two smaller 19 'HF peaks of 16 and $11 \%$ were recorded in the stomach on 11 April and 2 May, respectively; another increase was reported during August, although this only reached 5\% (Fig. 2d). During the first peak and the late summer increase, the proportion of this pigment in the rectum did not change, whereas it increased up to $8 \%$ just after the second spring peak. A higher proportion of alloxanthin was present in the rectum than in the stomach until mid-May (Fig. 2e). The proportion of this pigment then increased up to $5 \%$ in the stomach in late May. From June to October a regular increase was registered in the digestive tract of Pecten maximus. Finally, several events of increased proportions of $19^{\prime} \mathrm{BF}$ up to $5 \%$ were observed in the stomach as well as in the rectum during April and the first week of May, whereas only one significant peak occurred in the seawater at the end of April (Fig. 2f).

Degraded pigments, namely pheophorbide- $a$ and pheophytin- $a$, were also observed in both stomach and rectum (Fig. 5). High proportions (17 to 24\%) of these 2 pigments were already present in the stomach at the beginning of the study and dropped down to zero on 11 April. A brief increase of pheophytin- $a$ to $24 \%$ was noted on 18 April. A peak of degraded pigment was reached between 26 May and 6 June and a second event occurred between 27 July and 30 August. In the rectum, the level of degraded pigments very closely followed the pattern described for the stomach. Pheophytin- $a$, however, fluctuated less from June and varied between 6 and 16\%. Moreover, when compared to the total pigment found in the stomach (Fig. 5b), the proportions of degraded pigments seemed rather disconnected from the periods of increased ingestion. During the 4 periods of high total pigment concentration in the digestive tract, proportions of degraded pigments did not show any strong dynamics. Conversely, the 3 periods of high levels of degraded pigments identified in the gut of the scallops occurred after periods of low feeding activity and just before the ingestion peaks. 


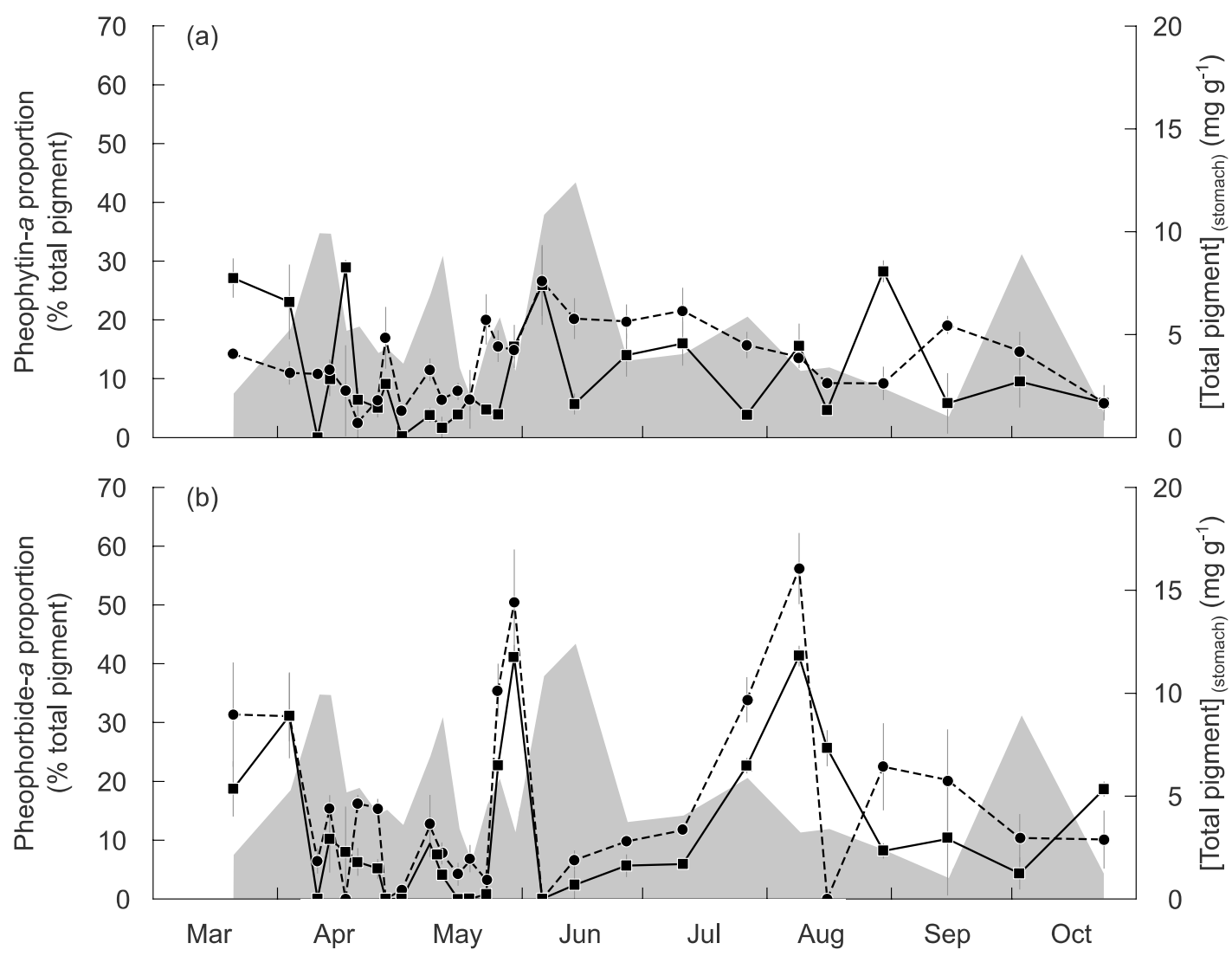

Figure 5. Total pigment concentration, including chlorophyll- $a$, in the stomach content of $P$. maximus (grey area, right axis) and proportions of (a) pheophorbide- $a$ and (b) pheophytin- $a$ in the stomach content (solid line, full squares) and the rectum content (dashed lines, full dots) of P. maximus in the Bay of Brest in 2011. Standard deviations are indicated by vertical grey lines.

\subsection{Fatty acid and sterol composition of the digestive gland}

First of all, the GC analysis of FAs and sterols in the seawater filters revealed extremely low quantities in the samples. Only the most prominent FAs could be detected, showing only small peaks which could not be accurately quantified. Several trials to concentrate the samples did not solve this detection threshold issue. Nevertheless, the absence of usable FA and sterol data for water samples should not be crippling for the study, as FA markers of microalgae classes observed here are well established in the literature. Moreover, data on quantitative microalgae compositions from optical and/or pigment analyses should constitute a sufficiently robust base for deciphering scallop FA profiles (see 'Discussion' for details).

The total amount of FAs and sterols in the DG of $P$. maximus showed particularly high variations during spring (Fig. 6f). Total FA content of the DG increased from 45 to $75 \mu \mathrm{mol} \mathrm{mg}^{-1}$ between the start and end of the study, with the highest value of $172 \mu \mathrm{mol} \mathrm{mg}^{-1}$ reached in mid-June (Fig. 6f). The main FAs found in the polar fraction were 20:5(n-3) (eicosapentaenoic acid; EPA), 22:6(n-3) (docosahexaenoic acid; DHA) and 16:0, each accounting for about 15\% of total FAs (Table 3), 18:4(n-3), 20:4(n-6), around $5 \%$ and to a lesser extent 18:2(n-6), 18:3(n-3), 18:1(n-9), 20:4(n-3) and iso17:0, which accounted for less than 2\%. In the neutral fraction, 20:5(n-3) was the main FA (25\%; Table 4), 16:0 accounted for about $15 \%, 14: 0,16: 1(n-7)$ and 22:6(n-3) ranged between 6 and 12\%, 20:4(n-6) was found around 3.5\% and 
18:1(n-9), 18:3(n-3), 18:4(n-3) and 18:5(n-3) each accounted for about $2 \%$. Within the polar fraction, the ratio between EPA and DHA showed 2 periods of increase in late April/early May and at the beginning of June (Fig. 6e). Lower levels were observed at the beginning of April, at the end of May and in August. An analogous tendency was observed when comparing the proportions of $16: 1(n-7)$ and $18: 5(n-3)$ (in the neutral fraction). A peak of 18:4(n-3) was observed at the end of April, its proportion reaching $5 \%$ of total FA and increasing regularly from June to October (Fig. 6c). Similar patterns were observed for 18:2(n-6) and 18:3(n-3), which also exhibited an important increase of twice their initial percentage in late May (Fig. 6a). The proportion of 20:4(n-3) only varied between 0.3 and $0.7 \%$, but presented 2 important peaks in April and in late May and gradually increased throughout the summer until the end

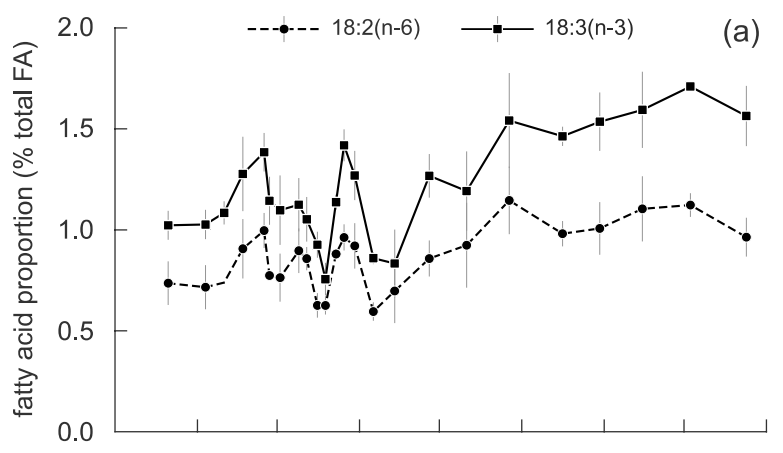

(b) - - - iso 17:0 - 20:4(n-3)

(a)
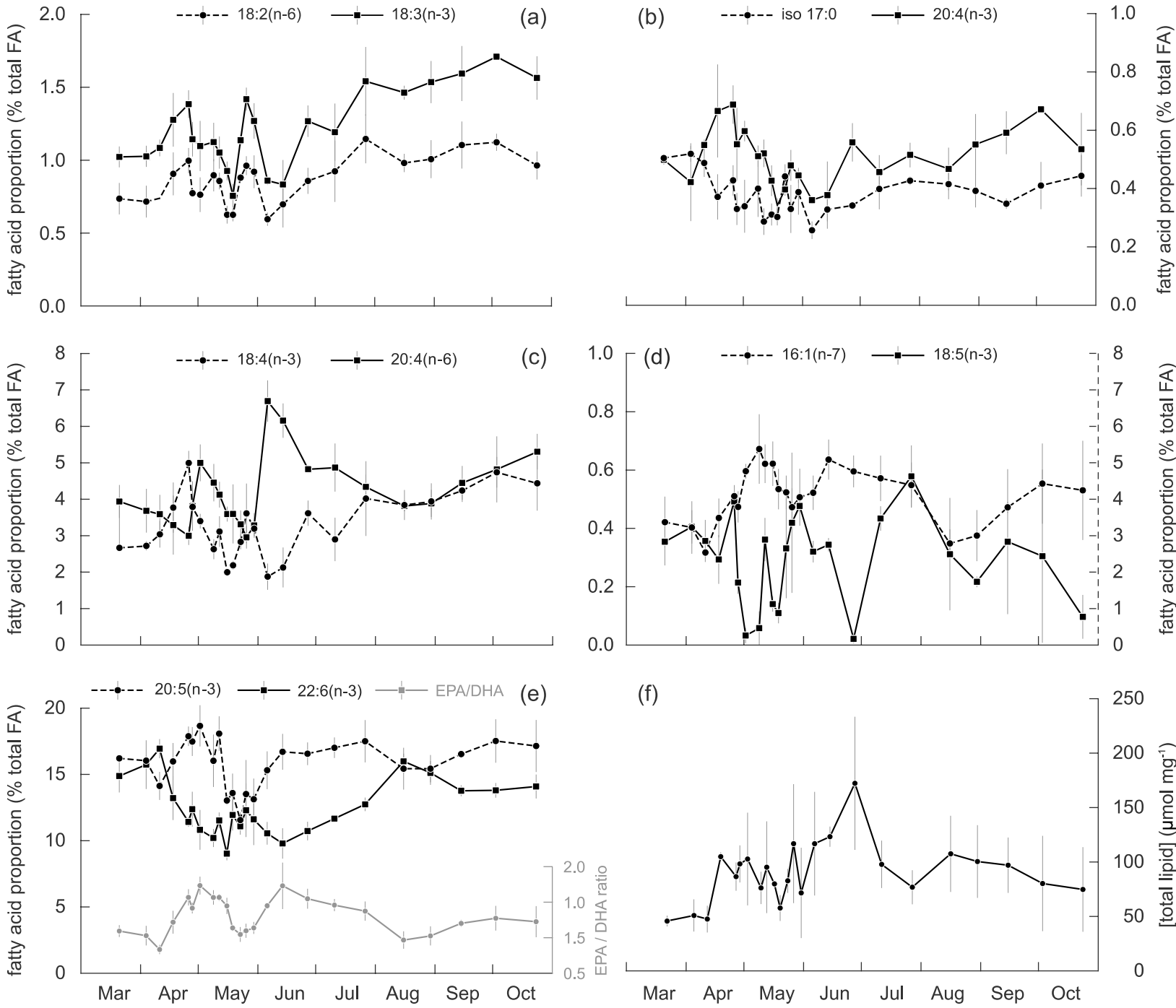

Fig. 6. Proportions of 10 major fatty acids in the digestive gland of Pecten maximus (expressed as fatty acid molar percentage of total) in the Bay of Brest in 2011. (a) 18:2(n-6) (dashed line, black dots), 18:3(n-3) (solid line, black squares) in polar lipids; (b) iso17:0 (dashed line, black dots) and 20:4(n-3) (solid line, black squares) in polar lipids; (c) 18:4(n-3) (solid line, black dots) and 20:4(n-6) (solid line, black squares) in polar lipids; (d) 16:1(n-7) (dashed line, black dots) in polar lipids and 18:5(n-3) (solid line, black squares) in neutral lipids; (e): 20:5(n-3) (dashed line, black dots), 22:6(n-3) (solid line, black squares) in polar lipids and their ratio (grey line, grey dots): 20:5(n-3)(EPA):22:6(n-3)(DHA); (f) total fatty acid concentration (polar plus neutral fractions, expressed in $\left.\mu \mathrm{mol} \mathrm{mg}^{-1}\right)$. Standard deviations are presented indicated by grey lines 
Table 3. Fatty acids (FA) composition of the polar lipids in the digestive gland of Pecten maximus (expressed as FA molar percentage of total) in the Bay of Brest in 2011. Standard deviations are in brackets. TMTD: 4,8,12-trimethyltridecanoic acid; SAFA: sum of saturated FA; MUFA: sum of monounsaturated FA; PUFA: sum of polyunsaturated FA; DMA: dimethyl acetals; (n-3): sum of $n-3$ polyunsaturated FA, (n-6): sum of $n-6$ polyunsaturated FA.

\begin{tabular}{|c|c|c|c|c|c|c|c|c|c|c|c|c|c|c|c|c|c|c|c|c|}
\hline Date & TMTD & 14:0 & 16:0 & iso17:0 & 18:0 & $16: 1(n-7)$ & $18: 1(n-9)$ & $18: 1(n-7)$ & $18: 2(n-6)$ & $18: 3(n-3)$ & $18: 4(n-3)$ & $20: 4(n-6)$ & $20: 5(n-3)$ & $22: 6(n-3)$ & SAFA & MUFA & PUFA & DMA & $(n-3)$ & $(n-6)$ \\
\hline 21/03 & $\begin{array}{l}8.3 \\
(7.8)\end{array}$ & $\begin{array}{l}3.0 \\
(0.1)\end{array}$ & $\begin{array}{l}11.5 \\
(0.7)\end{array}$ & $\begin{array}{l}0.5 \\
(0.0)\end{array}$ & $\begin{array}{l}8.6 \\
(1.1)\end{array}$ & $3.4(0.7)$ & $1.3(0.1)$ & $1.0(1.0)$ & $0.7(0.1)$ & $1.0(0.1)$ & $2.7(0.1)$ & $3.9(0.4)$ & $16.2(0.1)$ & $14.9(1.2)$ & $\begin{array}{l}24.9 \\
(0.6)\end{array}$ & $\begin{array}{l}8.6 \\
(1.0)\end{array}$ & $\begin{array}{l}47.3 \\
(2.5)\end{array}$ & $\begin{array}{l}10.3 \\
(3.8)\end{array}$ & $\begin{array}{l}38.5 \\
(2.6)\end{array}$ & $\begin{array}{l}6.4 \\
(1.0)\end{array}$ \\
\hline 04/04 & $\begin{array}{l}5.2 \\
(9.0)\end{array}$ & $\begin{array}{l}3.2 \\
(0.4)\end{array}$ & $\begin{array}{l}11.3 \\
(0.7)\end{array}$ & $\begin{array}{l}0.5 \\
(0.0)\end{array}$ & $\begin{array}{l}8.7 \\
(1.1)\end{array}$ & $3.2(0.7)$ & $1.2(0.2)$ & $1.4(1.2)$ & $0.7(0.1)$ & $1.0(0.1)$ & $2.7(0.1)$ & $3.7(0.6)$ & $16.0(0.4)$ & $15.7(1.8)$ & $\begin{array}{l}25.0 \\
(0.6)\end{array}$ & $\begin{array}{l}8.8 \\
(1.0)\end{array}$ & $\begin{array}{l}48.1 \\
(2.7)\end{array}$ & $\begin{array}{l}12.1 \\
(4.5)\end{array}$ & $\begin{array}{l}39.7 \\
(3.2)\end{array}$ & $\begin{array}{l}6.1 \\
(1.5)\end{array}$ \\
\hline 11/04 & $\begin{array}{l}1.9 \\
(3.3)\end{array}$ & $\begin{array}{l}3.2 \\
(0.3)\end{array}$ & $\begin{array}{l}13.3 \\
(0.9)\end{array}$ & $\begin{array}{l}0.5 \\
(0.1)\end{array}$ & $\begin{array}{l}8.9 \\
(0.6)\end{array}$ & $2.5(0.1)$ & $1.0(0.1)$ & $2.0(0.2)$ & $0.7(0.0)$ & $1.1(0.1)$ & $3.0(0.4)$ & $3.6(0.5)$ & $14.1(1.0)$ & $16.9(0.7)$ & $\begin{array}{l}27.6 \\
(2.0)\end{array}$ & $\begin{array}{l}8.8 \\
(0.3)\end{array}$ & $\begin{array}{l}49.5 \\
(1.4)\end{array}$ & $\begin{array}{l}11.7 \\
(1.3)\end{array}$ & $\begin{array}{l}40.2 \\
(1.8)\end{array}$ & $\begin{array}{l}6.5 \\
(0.8)\end{array}$ \\
\hline 18/04 & $\begin{array}{l}7.1 \\
(6.4)\end{array}$ & $\begin{array}{l}3.9 \\
(0.5)\end{array}$ & $\begin{array}{l}12.2 \\
(1.0)\end{array}$ & $\begin{array}{l}0.4 \\
(0.1)\end{array}$ & $\begin{array}{l}7.8 \\
(1.4)\end{array}$ & $3.5(0.5)$ & $1.3(0.0)$ & $2.1(0.2)$ & $0.9(0.1)$ & $1.3(0.2)$ & $3.8(0.7)$ & $3.3(0.8)$ & $16.0(1.4)$ & $13.2(1.6)$ & $\begin{array}{l}25.7 \\
(1.7)\end{array}$ & $\begin{array}{l}9.7 \\
(1.0)\end{array}$ & $\begin{array}{l}47.3 \\
(2.8)\end{array}$ & $\begin{array}{l}9.9 \\
(1.7)\end{array}$ & $\begin{array}{l}38.8 \\
(2.4)\end{array}$ & $\begin{array}{l}5.9 \\
(1.4)\end{array}$ \\
\hline 26/04 & $\begin{array}{l}8.0 \\
(1.8)\end{array}$ & $\begin{array}{l}3.9 \\
(0.1)\end{array}$ & $\begin{array}{l}14.0 \\
(1.0)\end{array}$ & $\begin{array}{l}0.4 \\
(0.1)\end{array}$ & $\begin{array}{l}7.9 \\
(0.3)\end{array}$ & $4.1(0.3)$ & $1.7(0.1)$ & $2.5(0.2)$ & $1.0(0.1)$ & $1.4(0.1)$ & $5.0(0.3)$ & $3.0(0.2)$ & $17.9(0.7)$ & $11.4(0.3)$ & $\begin{array}{l}26.7 \\
(0.7)\end{array}$ & $\begin{array}{l}11.1 \\
(0.8)\end{array}$ & $\begin{array}{l}47.5 \\
(1.7)\end{array}$ & $\begin{array}{l}6.4 \\
(0.3)\end{array}$ & $\begin{array}{l}39.9 \\
(0.8)\end{array}$ & $\begin{array}{l}5.4 \\
(0.9)\end{array}$ \\
\hline 28/04 & $\begin{array}{l}6.0 \\
(5.3)\end{array}$ & $\begin{array}{l}4.0 \\
(0.6)\end{array}$ & $\begin{array}{l}11.9 \\
(0.8)\end{array}$ & $\begin{array}{l}0.3 \\
(0.1)\end{array}$ & $\begin{array}{l}8.2 \\
(0.3)\end{array}$ & $3.8(0.4)$ & $1.2(0.1)$ & $2.6(0.2)$ & $0.8(0.0)$ & $1.1(0.1)$ & $3.8(0.8)$ & $3.8(0.7)$ & $17.5(1.1)$ & $12.4(1.3)$ & $\begin{array}{l}25.6 \\
(1.5)\end{array}$ & $\begin{array}{l}10.7 \\
(0.5)\end{array}$ & $\begin{array}{l}47.7 \\
(3.3)\end{array}$ & $\begin{array}{l}9.6 \\
(0.2)\end{array}$ & $\begin{array}{l}39.1 \\
(3.3)\end{array}$ & $\begin{array}{l}6.1 \\
(0.9)\end{array}$ \\
\hline $02 / 05$ & $\begin{array}{l}6.6 \\
(2.1)\end{array}$ & $\begin{array}{l}4.3 \\
(0.3)\end{array}$ & $\begin{array}{l}13.0 \\
(1.3)\end{array}$ & $\begin{array}{l}0.3 \\
(0.1)\end{array}$ & $\begin{array}{l}5.3 \\
(4.6)\end{array}$ & $4.8(0.2)$ & $1.2(0.2)$ & $3.5(0.2)$ & $0.8(0.1)$ & $1.1(0.2)$ & $3.4(0.2)$ & $5.0(0.5)$ & $18.7(1.5)$ & $10.8(1.5)$ & $\begin{array}{l}23.7 \\
(3.6)\end{array}$ & $\begin{array}{l}12.7 \\
(0.8)\end{array}$ & $\begin{array}{l}48.2 \\
(4.4)\end{array}$ & $\begin{array}{l}8.4 \\
(0.7)\end{array}$ & $\begin{array}{l}38.4 \\
(3.8)\end{array}$ & $\begin{array}{l}7.6 \\
(0.8)\end{array}$ \\
\hline 09/05 & $\begin{array}{l}4.9 \\
(2.1)\end{array}$ & $\begin{array}{l}4.0 \\
(1.3)\end{array}$ & $\begin{array}{l}14.9 \\
(1.6)\end{array}$ & $\begin{array}{l}0.4 \\
(0.1)\end{array}$ & $\begin{array}{l}9.0 \\
(0.2)\end{array}$ & $5.4(0.9)$ & $1.5(0.1)$ & $4.7(0.3)$ & $0.9(0.1)$ & $1.1(0.1)$ & $2.6(0.3)$ & $4.5(0.5)$ & $16.0(2.0)$ & $10.2(0.7)$ & $\begin{array}{l}29.1 \\
(2.4)\end{array}$ & $\begin{array}{l}14.9 \\
(0.9)\end{array}$ & $\begin{array}{l}42.9 \\
(3.6)\end{array}$ & $\begin{array}{l}7.9 \\
(1.2)\end{array}$ & $\begin{array}{l}33.5 \\
(2.5)\end{array}$ & $\begin{array}{l}7.1 \\
(1.2)\end{array}$ \\
\hline $12 / 05$ & $\begin{array}{l}5.9 \\
(0.8)\end{array}$ & $\begin{array}{l}4.0 \\
(0.5)\end{array}$ & $\begin{array}{l}14.3 \\
(1.2)\end{array}$ & $\begin{array}{l}0.3 \\
(0.0)\end{array}$ & $\begin{array}{l}5.4 \\
(4.7)\end{array}$ & $5.0(0.5)$ & $1.3(0.1)$ & $5.3(0.4)$ & $0.9(0.1)$ & $1.1(0.1)$ & $3.1(0.4)$ & $4.1(0.3)$ & $18.1(1.3)$ & $11.5(0.6)$ & $\begin{array}{l}25.3 \\
(3.0)\end{array}$ & $\begin{array}{l}14.5 \\
(1.2)\end{array}$ & $\begin{array}{l}46.6 \\
(2.2)\end{array}$ & $\begin{array}{l}7.4 \\
(0.2)\end{array}$ & $\begin{array}{l}37.7 \\
(2.3)\end{array}$ & $\begin{array}{l}6.7 \\
(0.8)\end{array}$ \\
\hline 16/05 & $\begin{array}{l}10.1 \\
(0.6)\end{array}$ & $\begin{array}{l}4.5 \\
(0.3)\end{array}$ & $\begin{array}{l}14.7 \\
(0.2)\end{array}$ & $\begin{array}{l}0.3 \\
(0.0)\end{array}$ & $\begin{array}{l}10.6 \\
(0.5)\end{array}$ & $5.0(0.6)$ & $1.4(0.2)$ & $4.5(0.3)$ & $0.6(0.1)$ & $0.9(0.1)$ & $2.0(0.1)$ & $3.6(0.2)$ & $13.0(0.3)$ & $9.0(0.5)$ & $\begin{array}{l}31.7 \\
(0.3)\end{array}$ & $\begin{array}{l}14.6 \\
(0.8)\end{array}$ & $\begin{array}{l}36.2 \\
(0.5)\end{array}$ & $\begin{array}{l}7.1 \\
(0.8)\end{array}$ & $\begin{array}{l}27.9 \\
(0.3)\end{array}$ & $\begin{array}{l}5.7 \\
(0.4)\end{array}$ \\
\hline 19/05 & $\begin{array}{l}7.0 \\
(6.1)\end{array}$ & $\begin{array}{l}4.3 \\
(0.5)\end{array}$ & $\begin{array}{l}15.2 \\
(0.9)\end{array}$ & $\begin{array}{l}0.3 \\
(0.0)\end{array}$ & $\begin{array}{l}9.4 \\
(0.5)\end{array}$ & $4.3(0.5)$ & $1.3(0.1)$ & $4.2(0.1)$ & $0.6(0.0)$ & $0.8(0.1)$ & $2.2(0.1)$ & $3.6(0.8)$ & $13.6(1.4)$ & $11.9(1.1)$ & $\begin{array}{l}31.2 \\
(1.7)\end{array}$ & $\begin{array}{l}13.3 \\
(0.5)\end{array}$ & $\begin{array}{l}40.8 \\
(3.9)\end{array}$ & $\begin{array}{l}7.5 \\
(1.6)\end{array}$ & $\begin{array}{l}31.8 \\
(2.9)\end{array}$ & $\begin{array}{l}5.8 \\
(1.2)\end{array}$ \\
\hline 23/05 & $\begin{array}{l}8.8 \\
(1.3)\end{array}$ & $\begin{array}{l}4.6 \\
(0.2)\end{array}$ & $\begin{array}{l}15.8 \\
(0.5)\end{array}$ & $\begin{array}{l}0.4 \\
(0.0)\end{array}$ & $\begin{array}{l}9.8 \\
(0.2)\end{array}$ & $4.2(0.4)$ & $1.8(0.1)$ & $3.5(0.2)$ & $0.9(0.0)$ & $1.1(0.0)$ & $2.8(0.2)$ & $3.3(0.4)$ & $11.6(0.6)$ & $11.1(0.6)$ & $\begin{array}{l}32.3 \\
(0.6)\end{array}$ & $\begin{array}{l}13.3 \\
(0.7)\end{array}$ & $\begin{array}{c}38.4 \\
(0.8)\end{array}$ & $\begin{array}{l}7.0 \\
(0.3)\end{array}$ & $\begin{array}{l}29.9 \\
(0.4)\end{array}$ & $\begin{array}{l}5.6 \\
(0.6)\end{array}$ \\
\hline 26/05 & $\begin{array}{l}6.9 \\
(1.3)\end{array}$ & $\begin{array}{l}3.9 \\
(0.8)\end{array}$ & $\begin{array}{l}15.3 \\
(1.3)\end{array}$ & $\begin{array}{l}0.3 \\
(0.0)\end{array}$ & $\begin{array}{l}9.5 \\
(0.6)\end{array}$ & $3.8(0.5)$ & $2.0(0.2)$ & $3.1(0.6)$ & $1.0(0.1)$ & $1.4(0.1)$ & $3.6(0.8)$ & $3.0(0.3)$ & $13.5(2.5)$ & $12.3(2.0)$ & $\begin{array}{l}30.6 \\
(2.8)\end{array}$ & $\begin{array}{l}12.4 \\
(1.9)\end{array}$ & $\begin{array}{l}41.9 \\
(5.9)\end{array}$ & $\begin{array}{l}7.8 \\
(0.2)\end{array}$ & $\begin{array}{l}34.2 \\
(5.7)\end{array}$ & $\begin{array}{l}5.4 \\
(0.6)\end{array}$ \\
\hline 30/05 & $\begin{array}{l}8.3 \\
(1.4)\end{array}$ & $\begin{array}{l}4.6 \\
(0.8)\end{array}$ & $\begin{array}{l}15.1 \\
(0.9)\end{array}$ & $\begin{array}{l}0.4 \\
(0.1)\end{array}$ & $\begin{array}{l}8.9 \\
(0.6)\end{array}$ & $4.1(0.8)$ & $1.8(0.3)$ & $2.9(0.4)$ & $0.9(0.1)$ & $1.3(0.1)$ & $3.2(0.2)$ & $3.3(0.3)$ & $13.1(1.5)$ & $11.6(1.9)$ & $\begin{array}{l}30.6 \\
(1.3)\end{array}$ & $\begin{array}{l}12.1 \\
(1.8)\end{array}$ & $\begin{array}{l}40.9 \\
(4.5)\end{array}$ & $\begin{array}{l}7.6 \\
(0.6)\end{array}$ & $\begin{array}{l}32.8 \\
(3.6)\end{array}$ & $\begin{array}{l}5.6 \\
(0.7)\end{array}$ \\
\hline 06/06 & $\begin{array}{l}7.6 \\
(0.0)\end{array}$ & $\begin{array}{l}5.7 \\
(0.4)\end{array}$ & $\begin{array}{l}12.4 \\
(0.9)\end{array}$ & $\begin{array}{l}0.3 \\
(0.1)\end{array}$ & $\begin{array}{l}8.1 \\
(0.6)\end{array}$ & $4.2(0.5)$ & $1.2(0.1)$ & $2.5(0.1)$ & $0.6(0.0)$ & $0.9(0.0)$ & $1.9(0.4)$ & $6.7(0.6)$ & $15.3(1.4)$ & $10.6(0.8)$ & $\begin{array}{l}27.5 \\
(0.9)\end{array}$ & $\begin{array}{l}11.0 \\
(0.6)\end{array}$ & $\begin{array}{l}47.5 \\
(1.7)\end{array}$ & $\begin{array}{l}6.1 \\
(0.6)\end{array}$ & $\begin{array}{l}32.1 \\
(2.6)\end{array}$ & $\begin{array}{l}9.4 \\
(1.2)\end{array}$ \\
\hline $14 / 06$ & $\begin{array}{l}6.1 \\
(1.5)\end{array}$ & $\begin{array}{l}5.4 \\
(0.3)\end{array}$ & $\begin{array}{l}13.6 \\
(1.4)\end{array}$ & $\begin{array}{l}0.3 \\
(0.0)\end{array}$ & $\begin{array}{l}8.4 \\
(0.3)\end{array}$ & $5.1(0.5)$ & $1.4(0.1)$ & $2.8(0.2)$ & $0.7(0.2)$ & $0.8(0.2)$ & $2.1(0.5)$ & $6.2(0.5)$ & $16.7(1.3)$ & $9.8(1.1)$ & $\begin{array}{l}29.2 \\
(1.3)\end{array}$ & $\begin{array}{l}12.3 \\
(0.9)\end{array}$ & $\begin{array}{l}44.1 \\
(0.5)\end{array}$ & $\begin{array}{l}7.9 \\
(1.1)\end{array}$ & $\begin{array}{l}32.9 \\
(0.8)\end{array}$ & $\begin{array}{l}8.7 \\
(0.8)\end{array}$ \\
\hline 27/06 & $\begin{array}{l}6.0 \\
(1.4)\end{array}$ & $\begin{array}{l}4.9 \\
(0.6)\end{array}$ & $\begin{array}{l}14.1 \\
(1.4)\end{array}$ & $\begin{array}{l}0.3 \\
(0.0)\end{array}$ & $\begin{array}{l}5.2 \\
(4.5)\end{array}$ & $4.8(0.4)$ & $1.5(0.1)$ & $2.9(0.2)$ & $0.9(0.1)$ & $1.3(0.1)$ & $3.6(0.3)$ & $4.8(0.1)$ & $16.6(0.8)$ & $10.7(0.7)$ & $\begin{array}{l}26.0 \\
(2.3)\end{array}$ & $\begin{array}{l}12.7 \\
(1.1)\end{array}$ & $\begin{array}{l}47.1 \\
(2.6)\end{array}$ & $\begin{array}{l}7.7 \\
(0.5)\end{array}$ & $\begin{array}{l}36.2 \\
(1.7)\end{array}$ & $\begin{array}{l}7.6 \\
(0.4)\end{array}$ \\
\hline 11/07 & $\begin{array}{l}5.8 \\
(1.7)\end{array}$ & $\begin{array}{l}4.7 \\
(0.4)\end{array}$ & $\begin{array}{l}14.8 \\
(0.7)\end{array}$ & $\begin{array}{l}0.4 \\
(0.0)\end{array}$ & $\begin{array}{l}8.5 \\
(0.6)\end{array}$ & $4.6(0.6)$ & $1.7(0.3)$ & $2.7(0.2)$ & $0.9(0.2)$ & $1.2(0.2)$ & $2.9(0.6)$ & $4.9(0.6)$ & $17.0(0.7)$ & $11.7(0.2)$ & $\begin{array}{l}29.3 \\
(0.7)\end{array}$ & $\begin{array}{l}11.9 \\
(0.9)\end{array}$ & $\begin{array}{l}46.3 \\
(1.1)\end{array}$ & $\begin{array}{l}6.3 \\
(0.9)\end{array}$ & $\begin{array}{l}36.1 \\
(1.7)\end{array}$ & $\begin{array}{l}7.7 \\
(1.8)\end{array}$ \\
\hline 27/07 & $\begin{array}{l}4.7 \\
(1.3)\end{array}$ & $\begin{array}{l}4.1 \\
(0.1)\end{array}$ & $\begin{array}{l}15.5 \\
(0.8)\end{array}$ & $\begin{array}{l}0.4 \\
(0.0)\end{array}$ & $\begin{array}{l}7.7 \\
(0.5)\end{array}$ & $4.4(0.6)$ & $2.1(0.4)$ & $2.7(0.1)$ & $1.1(0.2)$ & $1.5(0.2)$ & $4.0(1.0)$ & $4.3(0.3)$ & $17.5(1.6)$ & $12.7(0.5)$ & $\begin{array}{l}28.7 \\
(0.3)\end{array}$ & $\begin{array}{l}11.0 \\
(0.8)\end{array}$ & $\begin{array}{l}49.4 \\
(2.2)\end{array}$ & $\begin{array}{l}5.8 \\
(1.2)\end{array}$ & $\begin{array}{l}40.0 \\
(2.9)\end{array}$ & $\begin{array}{l}7.0 \\
(1.2)\end{array}$ \\
\hline 16/08 & $\begin{array}{l}4.7 \\
(0.3)\end{array}$ & $\begin{array}{l}3.2 \\
(0.3)\end{array}$ & $\begin{array}{l}13.8 \\
(0.2)\end{array}$ & $\begin{array}{l}0.4 \\
(0.1)\end{array}$ & $\begin{array}{l}7.7 \\
(0.6)\end{array}$ & $2.8(0.4)$ & $1.4(0.1)$ & $2.4(0.1)$ & $1.0(0.1)$ & $1.5(0.0)$ & $3.8(0.4)$ & $3.8(0.1)$ & $15.4(1.5)$ & $16.0(0.5)$ & $\begin{array}{l}25.9 \\
(1.0)\end{array}$ & $\begin{array}{l}9.2 \\
(0.9)\end{array}$ & $\begin{array}{l}53.0 \\
(1.4)\end{array}$ & $\begin{array}{l}6.9 \\
(0.2)\end{array}$ & $\begin{array}{l}40.3 \\
(2.0)\end{array}$ & $\begin{array}{l}6.3 \\
(0.4)\end{array}$ \\
\hline 30/08 & $\begin{array}{l}4.4 \\
(1.2)\end{array}$ & $\begin{array}{l}3.3 \\
(0.5)\end{array}$ & $\begin{array}{l}14.2 \\
(1.2)\end{array}$ & $\begin{array}{l}0.4 \\
(0.1)\end{array}$ & $\begin{array}{l}7.6 \\
(0.4)\end{array}$ & $3.0(0.7)$ & $1.5(0.2)$ & $2.5(0.1)$ & $1.0(0.1)$ & $1.5(0.1)$ & $3.9(0.5)$ & $3.9(0.4)$ & $15.4(1.0)$ & $15.1(0.9)$ & $\begin{array}{l}26.3 \\
(2.5)\end{array}$ & $\begin{array}{l}9.6 \\
(0.9)\end{array}$ & $\begin{array}{l}52.6 \\
(1.8)\end{array}$ & $\begin{array}{l}6.8 \\
(0.4)\end{array}$ & $\begin{array}{l}39.7 \\
(1.1)\end{array}$ & $\begin{array}{l}6.5 \\
(0.4)\end{array}$ \\
\hline 05/09 & $\begin{array}{l}3.2 \\
(0.3)\end{array}$ & $\begin{array}{l}3.8 \\
(0.1)\end{array}$ & $\begin{array}{l}15.2 \\
(1.1)\end{array}$ & $\begin{array}{l}0.4 \\
(0.0)\end{array}$ & $\begin{array}{l}7.7 \\
(0.3)\end{array}$ & $3.8(0.1)$ & $1.6(0.2)$ & $2.7(0.1)$ & $1.1(0.2)$ & $1.6(0.2)$ & $4.2(0.3)$ & $4.4(0.5)$ & $16.5(0.2)$ & $13.8(0.4)$ & $\begin{array}{l}28.5 \\
(1.3)\end{array}$ & $\begin{array}{l}10.8 \\
(0.3)\end{array}$ & $\begin{array}{l}50.1 \\
(0.5)\end{array}$ & $\begin{array}{l}7.1 \\
(0.9)\end{array}$ & $\begin{array}{l}40.3 \\
(0.6)\end{array}$ & $\begin{array}{l}7.1 \\
(0.4)\end{array}$ \\
\hline $03 / 10$ & $\begin{array}{l}3.3 \\
(0.4)\end{array}$ & $\begin{array}{l}2.8 \\
(1.9)\end{array}$ & $\begin{array}{l}15.6 \\
(0.1)\end{array}$ & $\begin{array}{l}0.4 \\
(0.1)\end{array}$ & $\begin{array}{l}7.2 \\
(1.4)\end{array}$ & $4.4(1.1)$ & $1.8(0.2)$ & $2.7(0.1)$ & $1.1(0.1)$ & $1.7(0.0)$ & $4.7(0.4)$ & $4.8(0.9)$ & $17.5(1.6)$ & $13.8(0.5)$ & $\begin{array}{l}27.4 \\
(3.1)\end{array}$ & $\begin{array}{l}11.6 \\
(1.8)\end{array}$ & $\begin{array}{l}51.7 \\
(2.1)\end{array}$ & $\begin{array}{l}5.6 \\
(1.4)\end{array}$ & $\begin{array}{l}41.2 \\
(0.5)\end{array}$ & $\begin{array}{l}7.6 \\
(1.0)\end{array}$ \\
\hline 24/10 & $\begin{array}{l}4.1 \\
(0.5)\end{array}$ & $\begin{array}{l}2.7 \\
\text { (1.9) }\end{array}$ & $\begin{array}{l}14.6 \\
(1.2)\end{array}$ & $\begin{array}{l}0.4 \\
(0.1)\end{array}$ & $\begin{array}{l}7.2 \\
(1.5)\end{array}$ & $4.2(1.4)$ & $1.8(0.2)$ & $2.6(0.2)$ & $1.0(0.1)$ & $1.6(0.1)$ & $4.4(0.7)$ & $5.3(0.5)$ & $17.1(1.9)$ & $14.1(0.9)$ & $\begin{array}{l}26.3 \\
(2.3)\end{array}$ & $\begin{array}{l}11.3 \\
(2.2)\end{array}$ & $\begin{array}{l}51.8 \\
(2.1)\end{array}$ & $\begin{array}{l}6.1 \\
(1.8)\end{array}$ & $\begin{array}{l}40.7 \\
(1.0)\end{array}$ & $\begin{array}{l}8.2 \\
(0.5)\end{array}$ \\
\hline
\end{tabular}


Table 4. Fatty acids (FA) composition of the neutral lipids in the digestive gland of Pecten maximus (expressed as FA molar percentage of total) in the Bay of Brest in 2011. Standard deviations are in brackets. TMTD: 4,8,12-trimethyltridecanoic acid; SAFA: sum of saturated FA; MUFA: sum of monounsaturated FA; PUFA: sum of polyunsaturated FA; DMA: dimethyl acetals; $(n-3)$ : sum of $n-3$ polyunsaturated FA; $(n-6)$ : sum of $n-6$ polyunsaturated FA.

\begin{tabular}{|c|c|c|c|c|c|c|c|c|c|c|c|c|c|c|c|c|c|c|c|c|}
\hline Date & TMTD & 14:0 & 16:0 & $16: 1(n-7)$ & $18: 1(n-9)$ & $18: 1(n-7)$ & $18: 2(n-6)$ & $18: 3(n-3)$ & $18: 4(n-3)$ & $18: 5(n-3)$ & $20: 4(n-6)$ & $20: 4(n-3)$ & $20: 5(n-3)$ & $22: 6(n-3)$ & SAFA & MUFA & PUFA & $D M A$ & $(n-3)$ & $(n-6)$ \\
\hline 21/03 & $\begin{array}{l}1.5 \\
(0.2)\end{array}$ & $\begin{array}{l}2.1 \\
(0.4)\end{array}$ & $\begin{array}{l}6.5 \\
(2.5)\end{array}$ & $8.8(0.4)$ & $2.8(0.0)$ & $3.8(0.1)$ & $2.1(0.0)$ & $2.2(0.0)$ & $6.5(0.0)$ & $0.4(0.1)$ & $3.3(0.0)$ & $1.0(0.5)$ & $23.0(0.0)$ & $6.8(0.0)$ & $\begin{array}{l}26.5 \\
(0.0)\end{array}$ & $\begin{array}{l}18.4 \\
(0.6)\end{array}$ & $\begin{array}{l}51.1 \\
(0.0)\end{array}$ & $\begin{array}{l}1.5 \\
(0.0)\end{array}$ & $\begin{array}{l}41.7 \\
(0.2)\end{array}$ & $\begin{array}{l}6.8 \\
(0.1)\end{array}$ \\
\hline 04/04 & $\begin{array}{l}2.0 \\
(0.4)\end{array}$ & $\begin{array}{l}2.1 \\
(0.1)\end{array}$ & $\begin{array}{l}7.9 \\
(2.3)\end{array}$ & $8.0(0.8)$ & $2.5(0.0)$ & $4.0(0.1)$ & $2.1(0.0)$ & $2.5(0.0)$ & $7.9(0.0)$ & $0.4(0.1)$ & $2.4(0.0)$ & $1.1(1.3)$ & $21.5(0.0)$ & $6.6(0.0)$ & $\begin{array}{l}27.1 \\
(0.0)\end{array}$ & $\begin{array}{l}18.1 \\
(0.3)\end{array}$ & $\begin{array}{l}50.4 \\
(0.1)\end{array}$ & $\begin{array}{l}1.4 \\
(0.0)\end{array}$ & $\begin{array}{l}41.9 \\
(0.3)\end{array}$ & $\begin{array}{l}6.0 \\
(0.2)\end{array}$ \\
\hline $11 / 04$ & $\begin{array}{l}1.6 \\
(0.4)\end{array}$ & $\begin{array}{l}2.3 \\
(0.4)\end{array}$ & $\begin{array}{l}9.9 \\
(0.9)\end{array}$ & $7.5(0.8)$ & $2.1(0.3)$ & $3.3(0.0)$ & $2.3(0.2)$ & $2.8(0.4)$ & $9.9(2.3)$ & $0.4(0.1)$ & $1.5(1.1)$ & $1.2(0.2)$ & $21.6(0.8)$ & $6.6(0.2)$ & $\begin{array}{l}27.0 \\
(1.5)\end{array}$ & $\begin{array}{l}15.7 \\
(1.0)\end{array}$ & $\begin{array}{l}53.1 \\
(2.1)\end{array}$ & $\begin{array}{l}2.2 \\
(0.4)\end{array}$ & $\begin{array}{l}44.9 \\
(2.3)\end{array}$ & $\begin{array}{l}5.2 \\
(0.8)\end{array}$ \\
\hline 18/04 & $\begin{array}{l}1.8 \\
(0.2)\end{array}$ & $\begin{array}{l}7.5 \\
(0.5)\end{array}$ & $\begin{array}{l}16.5 \\
(0.2)\end{array}$ & $8.1(0.6)$ & $1.8(1.3)$ & $3.6(0.1)$ & $1.9(0.4)$ & $2.1(0.7)$ & $8.3(1.2)$ & $0.3(0.1)$ & $2.5(0.3)$ & $1.3(0.2)$ & $21.8(1.3)$ & $6.6(0.4)$ & $\begin{array}{l}28.1 \\
(0.9)\end{array}$ & $\begin{array}{l}17.2 \\
(1.2)\end{array}$ & $\begin{array}{l}51.5 \\
(0.9)\end{array}$ & $\begin{array}{l}0.7 \\
(0.8)\end{array}$ & $\begin{array}{l}42.9 \\
(1.3)\end{array}$ & $\begin{array}{l}5.9 \\
(0.7)\end{array}$ \\
\hline 26/04 & $\begin{array}{l}1.8 \\
(0.2)\end{array}$ & $\begin{array}{l}8.1 \\
(0.7)\end{array}$ & $\begin{array}{l}14.3 \\
(4.2)\end{array}$ & $8.2(1.7)$ & $2.8(0.2)$ & $2.9(0.1)$ & $2.2(0.2)$ & $2.8(0.2)$ & $8.4(0.8)$ & $0.5(0.0)$ & $2.8(0.4)$ & $1.0(0.4)$ & $23.6(3.2)$ & $6.2(0.6)$ & $\begin{array}{l}26.3 \\
(4.0)\end{array}$ & $\begin{array}{l}17.5 \\
(2.7)\end{array}$ & $\begin{array}{l}53.4 \\
(6.2)\end{array}$ & $\begin{array}{l}0.2 \\
(0.1)\end{array}$ & $\begin{array}{l}44.7 \\
(5.1)\end{array}$ & $\begin{array}{l}6.4 \\
(0.6)\end{array}$ \\
\hline 28/04 & $\begin{array}{l}1.8 \\
(0.3)\end{array}$ & $\begin{array}{l}7.6 \\
(0.9)\end{array}$ & $\begin{array}{l}14.2 \\
(2.2)\end{array}$ & $9.4(0.4)$ & $1.7(1.0)$ & $3.8(0.2)$ & $2.4(0.3)$ & $2.3(1.0)$ & $8.9(2.9)$ & $0.2(0.0)$ & $2.6(1.1)$ & $1.3(0.4)$ & $24.6(0.7)$ & $6.6(0.9)$ & $\begin{array}{l}25.0 \\
(2.6)\end{array}$ & $\begin{array}{l}18.2 \\
(1.5)\end{array}$ & $\begin{array}{l}54.4 \\
(4.0)\end{array}$ & $\begin{array}{l}0.1 \\
(0.1)\end{array}$ & $\begin{array}{l}46.2 \\
(5.0)\end{array}$ & $\begin{array}{l}6.4 \\
(0.6)\end{array}$ \\
\hline $02 / 05$ & $\begin{array}{l}1.6 \\
(1.4)\end{array}$ & $\begin{array}{l}10.4 \\
(1.6)\end{array}$ & $\begin{array}{l}11.7 \\
(4.8)\end{array}$ & $7.2(3.2)$ & $2.8(0.2)$ & $3.6(0.2)$ & $1.6(0.2)$ & $2.6(0.4)$ & $7.7(1.4)$ & $0.0(0.0)$ & $3.2(0.4)$ & $0.7(0.2)$ & $25.8(5.5)$ & $6.4(1.6)$ & $\begin{array}{l}26.5 \\
(3.8)\end{array}$ & $\begin{array}{l}16.8 \\
(4.3)\end{array}$ & $\begin{array}{l}54.2 \\
(7.6)\end{array}$ & $\begin{array}{l}0.5 \\
(0.8)\end{array}$ & $\begin{array}{l}45.3 \\
(8.2)\end{array}$ & $\begin{array}{l}6.2 \\
(0.5)\end{array}$ \\
\hline 09/05 & $\begin{array}{l}1.1 \\
(1.0)\end{array}$ & $\begin{array}{l}10.5 \\
(3.2)\end{array}$ & $\begin{array}{l}13.4 \\
\text { (3.4) }\end{array}$ & $9.8(3.5)$ & $2.5(0.5)$ & $3.3(0.2)$ & $2.0(1.0)$ & $2.0(0.6)$ & $7.5(1.8)$ & $0.1(0.0)$ & $2.4(0.7)$ & $1.0(0.4)$ & $19.9(3.2)$ & $6.7(2.2)$ & $\begin{array}{l}29.5 \\
(4.3)\end{array}$ & $\begin{array}{l}19.7 \\
(5.7)\end{array}$ & $\begin{array}{l}48.3 \\
(1.8)\end{array}$ & $\begin{array}{l}0.7 \\
(0.8)\end{array}$ & $\begin{array}{l}39.5 \\
(1.5)\end{array}$ & $\begin{array}{l}5.9 \\
(1.0)\end{array}$ \\
\hline $12 / 05$ & $\begin{array}{l}1.8 \\
(0.0)\end{array}$ & $\begin{array}{l}8.3 \\
(0.3)\end{array}$ & $\begin{array}{l}15.8 \\
(0.6)\end{array}$ & $11.2(0.5)$ & $2.1(0.1)$ & $4.4(0.0)$ & $1.9(0.2)$ & $2.4(0.2)$ & $8.2(0.4)$ & $0.4(0.1)$ & $2.2(0.2)$ & $1.2(0.0)$ & $22.5(1.3)$ & $4.9(0.5)$ & $\begin{array}{l}28.0 \\
(0.9)\end{array}$ & $\begin{array}{l}20.7 \\
(0.7)\end{array}$ & $\begin{array}{l}48.0 \\
(1.6)\end{array}$ & $\begin{array}{l}0.2 \\
(0.0)\end{array}$ & $\begin{array}{l}41.4 \\
(1.5)\end{array}$ & $\begin{array}{l}5.4 \\
(0.1)\end{array}$ \\
\hline $16 / 05$ & $\begin{array}{l}1.8 \\
(0.1)\end{array}$ & $\begin{array}{l}8.6 \\
(0.3)\end{array}$ & $\begin{array}{l}17.7 \\
(0.2)\end{array}$ & $10.5(0.3)$ & $2.4(0.1)$ & $4.7(0.0)$ & $1.8(0.1)$ & $2.1(0.0)$ & $6.1(0.3)$ & $0.1(0.1)$ & $2.8(0.1)$ & $1.0(0.1)$ & $20.1(0.1)$ & $5.0(0.5)$ & $\begin{array}{l}31.3 \\
(0.1)\end{array}$ & $\begin{array}{l}21.3 \\
(0.5)\end{array}$ & $\begin{array}{l}44.6 \\
(0.5)\end{array}$ & $\begin{array}{l}0.2 \\
(0.0)\end{array}$ & $\begin{array}{l}36.2 \\
(0.5)\end{array}$ & $\begin{array}{l}5.9 \\
(0.0)\end{array}$ \\
\hline $19 / 05$ & $\begin{array}{l}2.5 \\
(0.2)\end{array}$ & $\begin{array}{l}9.3 \\
(0.3)\end{array}$ & $\begin{array}{l}18.1 \\
(0.3)\end{array}$ & $10.3(0.2)$ & $2.4(0.2)$ & $5.0(0.0)$ & $1.7(0.2)$ & $1.9(0.1)$ & $5.5(0.6)$ & $0.1(0.0)$ & $2.6(0.6)$ & $0.9(0.1)$ & $17.8(0.4)$ & $5.7(0.3)$ & $\begin{array}{l}32.7 \\
(0.2)\end{array}$ & $\begin{array}{l}21.7 \\
(0.6)\end{array}$ & $\begin{array}{l}42.3 \\
(0.8)\end{array}$ & $\begin{array}{l}0.2 \\
(0.1)\end{array}$ & $\begin{array}{l}34.0 \\
(0.5)\end{array}$ & $\begin{array}{l}5.7 \\
(0.9)\end{array}$ \\
\hline 23/05 & $\begin{array}{l}2.4 \\
(0.6)\end{array}$ & $\begin{array}{l}7.0 \\
(3.1)\end{array}$ & $\begin{array}{l}18.8 \\
(2.8)\end{array}$ & $12.0(1.5)$ & $3.0(1.1)$ & $1.5(0.1)$ & $2.3(0.0)$ & $2.4(0.2)$ & $6.1(0.2)$ & $0.3(0.2)$ & $2.8(1.0)$ & $0.9(0.3)$ & $18.5(4.3)$ & $5.9(1.1)$ & $\begin{array}{l}31.1 \\
(5.5)\end{array}$ & $\begin{array}{l}21.7 \\
(1.9)\end{array}$ & $\begin{array}{l}44.0 \\
(6.4)\end{array}$ & $\begin{array}{l}0.1 \\
(0.1)\end{array}$ & $\begin{array}{l}35.8 \\
(5.0)\end{array}$ & $\begin{array}{l}6.7 \\
(1.1)\end{array}$ \\
\hline $26 / 05$ & $\begin{array}{l}2.2 \\
(0.3)\end{array}$ & $\begin{array}{l}6.4 \\
(3.2)\end{array}$ & $\begin{array}{l}16.7 \\
(3.2)\end{array}$ & $13.2(3.2)$ & $2.2(0.8)$ & $4.9(0.1)$ & $2.3(0.4)$ & $2.0(0.6)$ & $5.9(1.4)$ & $0.4(0.2)$ & $2.4(0.8)$ & $1.1(0.2)$ & $19.1(7.0)$ & $7.2(2.5)$ & $\begin{array}{l}27.1 \\
(7.1)\end{array}$ & $\begin{array}{l}23.5 \\
(3.0)\end{array}$ & $\begin{array}{l}46.1 \\
(10.0)\end{array}$ & $\begin{array}{l}0.1 \\
(0.1)\end{array}$ & $\begin{array}{l}37.8 \\
(9.6)\end{array}$ & $\begin{array}{l}6.3 \\
(1.6)\end{array}$ \\
\hline 30/05 & $\begin{array}{l}2.9 \\
(0.8)\end{array}$ & $\begin{array}{l}9.3 \\
(0.5)\end{array}$ & $\begin{array}{l}20.2 \\
(3.3)\end{array}$ & $9.2(0.4)$ & $3.2(0.9)$ & $4.0(0.3)$ & $1.2(1.3)$ & $1.7(1.1)$ & $8.4(3.8)$ & $0.5(0.2)$ & $2.5(1.0)$ & $0.7(0.2)$ & $13.4(0.4)$ & $6.6(2.2)$ & $\begin{array}{l}35.2 \\
(4.2)\end{array}$ & $\begin{array}{l}21.2 \\
(2.3)\end{array}$ & $\begin{array}{l}39.5 \\
(5.0)\end{array}$ & $\begin{array}{l}0.4 \\
(0.3)\end{array}$ & $\begin{array}{l}32.5 \\
(5.0)\end{array}$ & $\begin{array}{l}4.8 \\
(0.0)\end{array}$ \\
\hline 06/06 & $\begin{array}{l}2.3 \\
(0.6)\end{array}$ & $\begin{array}{l}10.1 \\
(0.6)\end{array}$ & $\begin{array}{l}12.4 \\
(4.1)\end{array}$ & $8.8(3.3)$ & $1.9(0.8)$ & $4.0(0.1)$ & $1.6(0.1)$ & $1.9(0.2)$ & $5.3(1.2)$ & $0.3(0.0)$ & $4.9(0.9)$ & $0.7(0.2)$ & $25.6(2.7)$ & $5.6(1.7)$ & $\begin{array}{l}26.8 \\
(4.0)\end{array}$ & $\begin{array}{l}18.1 \\
(5.3)\end{array}$ & $\begin{array}{l}52.0 \\
(4.5)\end{array}$ & $\begin{array}{l}0.1 \\
(0.0)\end{array}$ & $\begin{array}{l}41.6 \\
(4.9)\end{array}$ & $\begin{array}{l}8.2 \\
(1.0)\end{array}$ \\
\hline $14 / 06$ & $\begin{array}{l}2.5 \\
(0.5)\end{array}$ & $\begin{array}{l}10.0 \\
(0.4)\end{array}$ & $\begin{array}{l}16.3 \\
(1.9)\end{array}$ & $11.3(0.3)$ & $2.6(0.3)$ & $1.5(0.0)$ & $1.0(0.3)$ & $2.4(0.4)$ & $6.2(0.9)$ & $0.3(0.0)$ & $3.8(0.5)$ & $0.9(0.1)$ & $22.7(1.2)$ & $5.4(0.6)$ & $\begin{array}{l}30.3 \\
(2.1)\end{array}$ & $\begin{array}{l}17.7 \\
(0.7)\end{array}$ & $\begin{array}{l}48.5 \\
(1.1)\end{array}$ & $\begin{array}{l}0.2 \\
(0.0)\end{array}$ & $\begin{array}{l}39.7 \\
(2.1)\end{array}$ & $\begin{array}{l}6.0 \\
(0.8)\end{array}$ \\
\hline $27 / 06$ & $\begin{array}{l}2.9 \\
(0.3)\end{array}$ & $\begin{array}{l}10.4 \\
(0.2)\end{array}$ & $\begin{array}{l}14.0 \\
(0.7)\end{array}$ & $10.4(3.0)$ & $2.2(0.6)$ & $2.2(0.0)$ & $0.8(0.5)$ & $2.2(1.0)$ & $8.7(0.6)$ & $0.0(0.0)$ & $3.4(0.4)$ & $0.7(0.1)$ & $23.0(0.5)$ & $6.8(0.7)$ & $\begin{array}{l}27.3 \\
(0.8)\end{array}$ & $\begin{array}{l}18.0 \\
(1.7)\end{array}$ & $\begin{array}{l}50.8 \\
(2.3)\end{array}$ & $\begin{array}{l}0.2 \\
(0.1)\end{array}$ & $\begin{array}{l}43.4 \\
(1.6)\end{array}$ & $\begin{array}{l}5.5 \\
(0.5)\end{array}$ \\
\hline $11 / 07$ & $\begin{array}{l}3.9 \\
(3.3)\end{array}$ & $\begin{array}{l}9.3 \\
(0.9)\end{array}$ & $\begin{array}{l}13.5 \\
(2.4)\end{array}$ & $9.6(1.4)$ & $1.6(0.8)$ & $3.2(0.1)$ & $1.7(0.4)$ & $2.3(0.2)$ & $6.5(0.4)$ & $0.4(0.0)$ & $3.7(0.6)$ & $1.0(0.1)$ & $24.3(2.1)$ & $6.8(0.6)$ & $\begin{array}{l}25.7 \\
(3.0)\end{array}$ & $\begin{array}{l}17.4 \\
(2.2)\end{array}$ & $\begin{array}{l}51.6 \\
(2.6)\end{array}$ & $\begin{array}{l}0.5 \\
(0.5)\end{array}$ & $\begin{array}{l}42.6 \\
(1.9)\end{array}$ & $\begin{array}{l}6.9 \\
(0.3)\end{array}$ \\
\hline $27 / 07$ & $\begin{array}{l}1.9 \\
(0.4)\end{array}$ & $\begin{array}{l}5.8 \\
\text { (3.3) }\end{array}$ & $\begin{array}{l}12.6 \\
(3.2)\end{array}$ & $10.0(0.9)$ & $3.0(0.4)$ & $3.9(0.2)$ & $2.2(0.3)$ & $2.6(0.1)$ & $7.2(0.5)$ & $0.6(0.1)$ & $3.5(0.6)$ & $0.9(0.1)$ & $22.3(2.2)$ & $7.7(0.3)$ & $\begin{array}{l}22.9 \\
(6.3)\end{array}$ & $\begin{array}{l}20.8 \\
(2.0)\end{array}$ & $\begin{array}{l}52.8 \\
(4.1)\end{array}$ & $\begin{array}{l}0.3 \\
(0.1)\end{array}$ & $\begin{array}{l}43.3 \\
(2.7)\end{array}$ & $\begin{array}{l}7.4 \\
(1.1)\end{array}$ \\
\hline $16 / 08$ & $\begin{array}{l}2.2 \\
(0.5)\end{array}$ & $\begin{array}{l}8.3 \\
(0.6)\end{array}$ & $\begin{array}{l}13.8 \\
(0.9)\end{array}$ & $9.4(2.2)$ & $1.6(0.1)$ & $3.0(0.1)$ & $1.7(0.9)$ & $2.9(0.3)$ & $7.4(0.2)$ & $0.3(0.2)$ & $2.8(1.0)$ & $1.2(0.1)$ & $24.0(1.2)$ & $7.4(2.3)$ & $\begin{array}{l}25.9 \\
(0.7)\end{array}$ & $\begin{array}{l}18.0 \\
(1.6)\end{array}$ & $\begin{array}{l}53.5 \\
(2.6)\end{array}$ & $\begin{array}{l}0.1 \\
(0.1)\end{array}$ & $\begin{array}{l}44.9 \\
(0.6)\end{array}$ & $\begin{array}{l}6.0 \\
(1.6)\end{array}$ \\
\hline 30/08 & $\begin{array}{l}1.8 \\
(0.1)\end{array}$ & $\begin{array}{l}8.5 \\
(0.3)\end{array}$ & $\begin{array}{l}15.2 \\
(2.6)\end{array}$ & $8.0(1.0)$ & $1.8(0.5)$ & $4.0(0.0)$ & $2.4(0.4)$ & $2.9(0.4)$ & $7.3(0.2)$ & $0.2(0.0)$ & $3.1(0.2)$ & $1.0(0.0)$ & $21.9(1.2)$ & $7.3(1.3)$ & $\begin{array}{l}27.9 \\
(3.2)\end{array}$ & $\begin{array}{l}17.3 \\
(0.3)\end{array}$ & $\begin{array}{l}52.3 \\
(3.7)\end{array}$ & $\begin{array}{l}0.2 \\
(0.0)\end{array}$ & $\begin{array}{l}42.4 \\
(2.8)\end{array}$ & $\begin{array}{l}6.7 \\
(0.6)\end{array}$ \\
\hline $05 / 09$ & $\begin{array}{l}1.6 \\
(0.3)\end{array}$ & $\begin{array}{l}7.9 \\
(0.9)\end{array}$ & $\begin{array}{l}17.0 \\
(4.2)\end{array}$ & $7.9(1.3)$ & $2.2(1.1)$ & $2.7(0.1)$ & $2.4(0.5)$ & $2.9(0.5)$ & $7.8(1.3)$ & $0.4(0.3)$ & $3.0(0.3)$ & $1.1(0.2)$ & $21.9(3.0)$ & $7.5(1.8)$ & $\begin{array}{l}28.6 \\
(4.6)\end{array}$ & $\begin{array}{l}15.9 \\
(2.2)\end{array}$ & $\begin{array}{l}53.2 \\
(7.2)\end{array}$ & $\begin{array}{l}0.2 \\
(0.0)\end{array}$ & $\begin{array}{l}43.7 \\
(6.6)\end{array}$ & $\begin{array}{l}6.7 \\
(0.7)\end{array}$ \\
\hline $03 / 10$ & $\begin{array}{l}3.0 \\
(2.5)\end{array}$ & $\begin{array}{l}7.1 \\
(2.7)\end{array}$ & $\begin{array}{l}13.0 \\
(1.6)\end{array}$ & $5.5(1.3)$ & $1.9(1.3)$ & $2.6(0.2)$ & $2.1(1.1)$ & $2.5(1.6)$ & $7.4(3.0)$ & $0.3(0.3)$ & $4.4(1.7)$ & $0.8(0.5)$ & $22.9(3.5)$ & $11.0(3.8)$ & $\begin{array}{l}26.1 \\
(3.5)\end{array}$ & $\begin{array}{l}12.3 \\
(3.2)\end{array}$ & $\begin{array}{l}58.0 \\
(3.6)\end{array}$ & $\begin{array}{l}0.3 \\
(0.2)\end{array}$ & $\begin{array}{l}47.3 \\
(4.5)\end{array}$ & $\begin{array}{l}7.9 \\
(0.7)\end{array}$ \\
\hline $24 / 10$ & $\begin{array}{l}3.0 \\
(2.2)\end{array}$ & $\begin{array}{l}6.8 \\
(2.8)\end{array}$ & $\begin{array}{l}11.1 \\
(3.2)\end{array}$ & $6.3(2.7)$ & $2.6(1.3)$ & $1.9(0.4)$ & $2.0(1.1)$ & $2.5(1.7)$ & $7.5(3.3)$ & $0.1(0.1)$ & $4.4(1.3)$ & $0.7(0.5)$ & $22.3(4.0)$ & $10.5(3.4)$ & $\begin{array}{l}23.6 \\
(5.2)\end{array}$ & $\begin{array}{l}14.3 \\
(6.0)\end{array}$ & $\begin{array}{l}56.0 \\
(4.6)\end{array}$ & $\begin{array}{l}2.8 \\
(3.7)\end{array}$ & $\begin{array}{l}46.0 \\
(5.5)\end{array}$ & $\begin{array}{l}7.9 \\
(0.3)\end{array}$ \\
\hline
\end{tabular}


of the study (Fig. 6b). Finally, iso17:0 FA found in the PLs presented interesting dynamics as it decreased from March to the end of May before rising again during summer and reaching a median value at the end of monitoring. Interestingly, our results suggest that most FAs assimilated as reserve compounds (neutral fraction), except 18:5(n-3), were hardly related to the short-term seasonal patterns observed through the analysis of pigments and PLs.

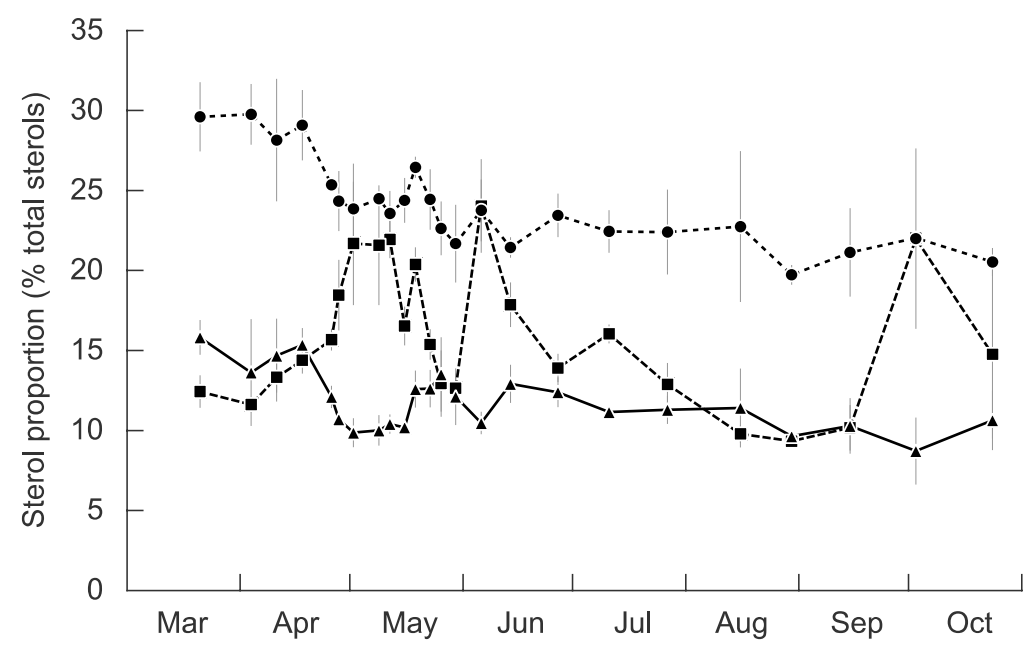

Fig. 7. Proportion of cholesterol (dotted line, black dots), 24 methylene cholesterol (dashed line, black squares) and brassicasterol (solid line, black triangles) in the digestive gland of Pecten maximus (expressed as sterol percentage of total) in the Bay of Brest in 2011. Standard deviations are indicated by vertical grey lines

Sterol content in the DG increased from 35.9 to $105.3 \mu \mathrm{g} \mathrm{g}^{-1}$ with a peak at $183.0 \mu \mathrm{g} \mathrm{g}^{-1}$ on 19 May (Table 5). Cholesta-5-e(n-3) $\beta$-ol (cholesterol) was, on average, the most common sterolic compound $(24 \%)$, followed by $5 \beta$-cholesta(n-3) $\beta$-ol (coprostanol; $21.6 \%$ ), $24 \beta$-methylenecholesta-

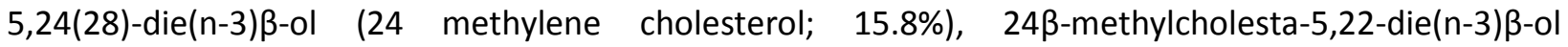
(brassicasterol; $11.8 \%$ ) and $24 \beta$-ethylenecholesta-5-e(n-3) $\beta$-ol ( $\beta$-sitosterol; $5.4 \%$ ). Cholesterol de creased slowly from 29.5 to $20.5 \%$ during the study period, without any strong variation (Fig. 7 ). The evolution of 24 methylene cholesterol followed the same dynamics as fucoxanthin in the stomach content, and EPA or 16:1(n-7) in the DG. A first increase was observed in May, lasting for 2 wk with a maximum at $22 \%$. It was followed by a second, more intense peak in early June, up to $24 \%$, and a final increase in late September to about the same level as the first spring peak. Brassicasterol showed an inverse dynamic: it decreased to $10 \%$ from mid-April to mid-May, then increased at the end of the month before reaching a plateau in summer and finally slightly decreasing again from mid-August until the end of the study. 
Table 5. Sterol composition of the digestive gland of Pecten maximus (expressed as sterol percentage of total) in the Bay of Brest in 2011. NOR: norcholesterol; CHO: cholesterol; BRA: brassicasterol; DES: desmosterol; CAM: campesterol; 24M: 24 methylene; STI: stigmasterol; BSI: $\beta$-sitosterol; FUS: fucosterol; OTH: other sterols; TOT: total sterol concentration (in $\mu \mathrm{mol} \mathrm{g}^{-1}$ ). Standard deviations are in brackets

\begin{tabular}{|c|c|c|c|c|c|c|c|c|c|c|c|}
\hline Date (dd/mo) & NOR & $\mathrm{CHO}$ & BRA & DES & CAM & $24 M$ & STI & BSI & FUC & OTH & TOT \\
\hline $21 / 03$ & $4.0(0.4)$ & $29.6(2.1)$ & 15.8 (1.1) & $4.6(0.3)$ & $2.5(0.2)$ & $12.4(1.0)$ & $3.3(0.6)$ & $6.9(0.4)$ & $1.7(0.2)$ & $19.2(1.3)$ & 46.77 (3.74) \\
\hline 04/04 & $4.3(0.2)$ & 29.8 (1.9) & $13.6(3.3)$ & $4.0(1.3)$ & $2.3(0.5)$ & $11.6(0.4)$ & $3.0(1.0)$ & $5.9(1.4)$ & $1.5(0.4)$ & $23.9(0.8)$ & $50.85(10.28)$ \\
\hline $11 / 04$ & $4.1(0.5)$ & $28.1(3.8)$ & $14.7(2.3)$ & $3.7(0.3)$ & $2.5(0.3)$ & $13.3(1.5)$ & $2.9(0.3)$ & $5.9(0.8)$ & $1.7(0.3)$ & $23.5(1.3)$ & $35.92(10.31)$ \\
\hline $18 / 04$ & $4.3(0.2)$ & $29.1(2.2)$ & $15.4(1.0)$ & $2.9(0.2)$ & $2.1(0.1)$ & $14.4(0.8)$ & $2.9(0.4)$ & $6.1(0.6)$ & $1.6(0.2)$ & $21.8(0.6)$ & 55.65 (5.89) \\
\hline $26 / 04$ & $3.6(0.5)$ & $25.4(0.4)$ & $12.1(0.7)$ & $2.2(0.8)$ & $1.9(0.1)$ & $15.7(0.7)$ & $2.1(0.3)$ & $5.3(0.8)$ & $1.9(0.2)$ & $29.8(0.4)$ & $58.81(1.80)$ \\
\hline $28 / 04$ & $2.7(0.1)$ & $24.3(1.8)$ & $10.7(0.4)$ & $2.8(0.6)$ & $1.7(0.1)$ & $18.5(2.2)$ & $2.5(0.3)$ & $5.6(1.1)$ & $1.6(0.2)$ & $30.1(0.7)$ & $53.73(6.10)$ \\
\hline 02/05 & $3.3(0.4)$ & $23.9(2.8)$ & $9.9(0.9)$ & $2.2(0.2)$ & $1.9(0.1)$ & 21.7 (3.8) & $2.5(0.4)$ & $5.0(0.9)$ & $1.3(0.0)$ & $28.5(0.4)$ & 50.75 (9.01) \\
\hline 09/05 & $3.6(0.3)$ & $24.5(0.4)$ & $10.0(0.9)$ & $1.8(0.2)$ & $1.7(0.2)$ & $21.6(3.7)$ & $2.5(0.5)$ & $5.0(0.2)$ & $1.3(0.1)$ & $27.9(0.6)$ & 49.75 (3.02) \\
\hline $12 / 05$ & $3.2(0.1)$ & 23.6 (1.4) & $10.4(0.6)$ & $2.9(0.3)$ & $1.8(0.3)$ & 21.9 (1.1) & $3.0(0.5)$ & $6.4(0.3)$ & $1.3(0.5)$ & $25.4(0.3)$ & 47.28 (3.71) \\
\hline $16 / 05$ & $3.4(0.3)$ & $24.4(1.4)$ & $10.2(0.1)$ & $2.9(0.7)$ & $1.7(0.5)$ & $16.5(1.2)$ & $3.1(0.3)$ & $6.2(0.6)$ & $1.4(0.1)$ & $30.1(0.4)$ & $44.42(3.44)$ \\
\hline 19/05 & $0.0(0.0)$ & $26.4(0.6)$ & $12.6(1.1)$ & $3.9(0.5)$ & $2.3(0.1)$ & $20.4(1.0)$ & $4.1(0.7)$ & $7.3(0.8)$ & $2.0(0.4)$ & $20.9(1.2)$ & 41.18 (6.64) \\
\hline $23 / 05$ & $3.7(0.2)$ & 24.4 (1.9) & $12.6(1.1)$ & $2.9(0.4)$ & $2.2(0.1)$ & $15.4(0.9)$ & $3.3(0.2)$ & $6.2(0.6)$ & $1.7(0.3)$ & $27.6(1.6)$ & $48.88(7.28)$ \\
\hline $26 / 05$ & $3.6(0.1)$ & $22.6(1.7)$ & $13.5(2.3)$ & $2.7(0.5)$ & $2.3(0.2)$ & $12.9(2.0)$ & $3.4(0.7)$ & $6.3(1.0)$ & $2.0(0.3)$ & $30.7(0.7)$ & $52.73(8.72)$ \\
\hline 30/05 & $3.0(0.4)$ & $21.7(2.4)$ & $12.1(1.7)$ & $3.2(0.6)$ & $2.0(0.2)$ & $12.6(0.9)$ & $3.0(1.0)$ & $5.7(1.4)$ & $1.7(0.4)$ & $34.9(1.1)$ & $73.73(9.28)$ \\
\hline 06/06 & $3.4(0.2)$ & $23.8(1.9)$ & $10.5(0.7)$ & $2.2(0.1)$ & $2.4(0.4)$ & $24.0(2.9)$ & $2.5(0.3)$ & $4.8(0.6)$ & $1.1(0.0)$ & $26.5(0.5)$ & 183.08 (4.59) \\
\hline $14 / 06$ & $2.6(0.1)$ & $21.4(0.6)$ & $12.9(1.2)$ & $2.8(0.4)$ & $3.2(0.4)$ & 17.9 (1.4) & $2.0(0.4)$ & $4.9(0.8)$ & $1.2(0.2)$ & $31.1(0.4)$ & $66.02(5.00)$ \\
\hline $27 / 06$ & $3.3(0.1)$ & $23.4(1.3)$ & $12.4(0.9)$ & $2.4(0.1)$ & $2.2(0.2)$ & $13.9(0.9)$ & $2.7(0.2)$ & $4.7(0.1)$ & $1.4(0.1)$ & $33.6(0.8)$ & 62.34 (4.91) \\
\hline $11 / 07$ & $2.5(0.3)$ & $22.4(1.3)$ & $11.1(0.3)$ & $3.5(0.7)$ & $1.9(0.2)$ & $16.0(0.6)$ & $2.4(0.3)$ & $4.9(0.3)$ & $0.9(0.5)$ & $34.3(1.2)$ & 63.79 (2.78) \\
\hline $27 / 07$ & $2.4(0.1)$ & $22.4(2.6)$ & $11.3(0.8)$ & $2.8(1.2)$ & $2.3(0.2)$ & $12.9(1.3)$ & $2.6(0.4)$ & $4.9(0.5)$ & $1.8(0.5)$ & $37.4(1.7)$ & $54.35(9.16)$ \\
\hline $16 / 08$ & $2.8(0.6)$ & $22.7(4.7)$ & $11.4(2.4)$ & $2.3(1.1)$ & $2.3(0.1)$ & $9.8(0.5)$ & $2.7(0.2)$ & $6.4(2.2)$ & $2.0(0.1)$ & $42.4(1.5)$ & 42.89 (4.49) \\
\hline 30/08 & $2.4(0.3)$ & $19.7(0.6)$ & $9.6(0.0)$ & $2.7(0.3)$ & $2.1(0.1)$ & $9.3(0.1)$ & $2.6(0.3)$ & $4.5(0.3)$ & $1.6(0.4)$ & $45.2(0.5)$ & $91.12(0.88)$ \\
\hline 05/09 & $2.9(0.2)$ & $21.1(2.7)$ & $10.3(1.7)$ & $1.5(0.9)$ & $2.2(0.4)$ & $10.2(1.4)$ & $2.5(0.7)$ & $3.2(1.5)$ & $1.5(0.4)$ & $44.7(0.8)$ & $98.50(6.42)$ \\
\hline $03 / 10$ & $1.9(0.3)$ & $22.0(0.4)$ & $8.7(2.1)$ & $1.3(0.9)$ & $1.8(0.3)$ & $22.0(5.6)$ & $2.3(0.5)$ & $2.6(1.7)$ & $1.3(0.2)$ & $36.2(1.4)$ & $65.43(3.47)$ \\
\hline $24 / 10$ & $3.0(0.4)$ & $20.5(0.8)$ & $10.6(1.8)$ & $2.0(0.6)$ & $2.2(0.3)$ & $14.8(5.2)$ & $2.1(0.1)$ & $4.4(0.6)$ & $1.6(0.2)$ & $39.5(0.5)$ & $105.31(8.02)$ \\
\hline
\end{tabular}




\subsection{Multivariate analysis}

The CCA shown in Fig. 8 validates the observations made through the analyses of the different biochemical markers used in this study, even though the eigenvalues of the CCA axes are not very high (10 to $40.8 \%$ of variance explained). Only the most prominent markers identified previously were selected and used in this analysis, since the high number of markers, their variability and the fact that some are less specific of certain microalgae produced results that were hardly interpretable in early trials. The best explained dispersion occurs along the first axis in the pigment analysis (Fig. 8a), differentiating between diatom markers on the left-hand side of the axis and markers of other food sources on the opposite side. Another distinction arises along the second axis, showing markers for diatoms and Dinophyceae in the upper part and other microalgae markers in the lower part. The same trend emerged from the CCA conducted on lipid markers (Fig. 8b), with diatom markers, as well as, to a lesser extent Dinophyceae, clearly distributed away from others. Another observation common to both plots is the clear distinction between microalgae from the water column and those from the water-sediment interface, again confirming the temporal shift reported earlier.

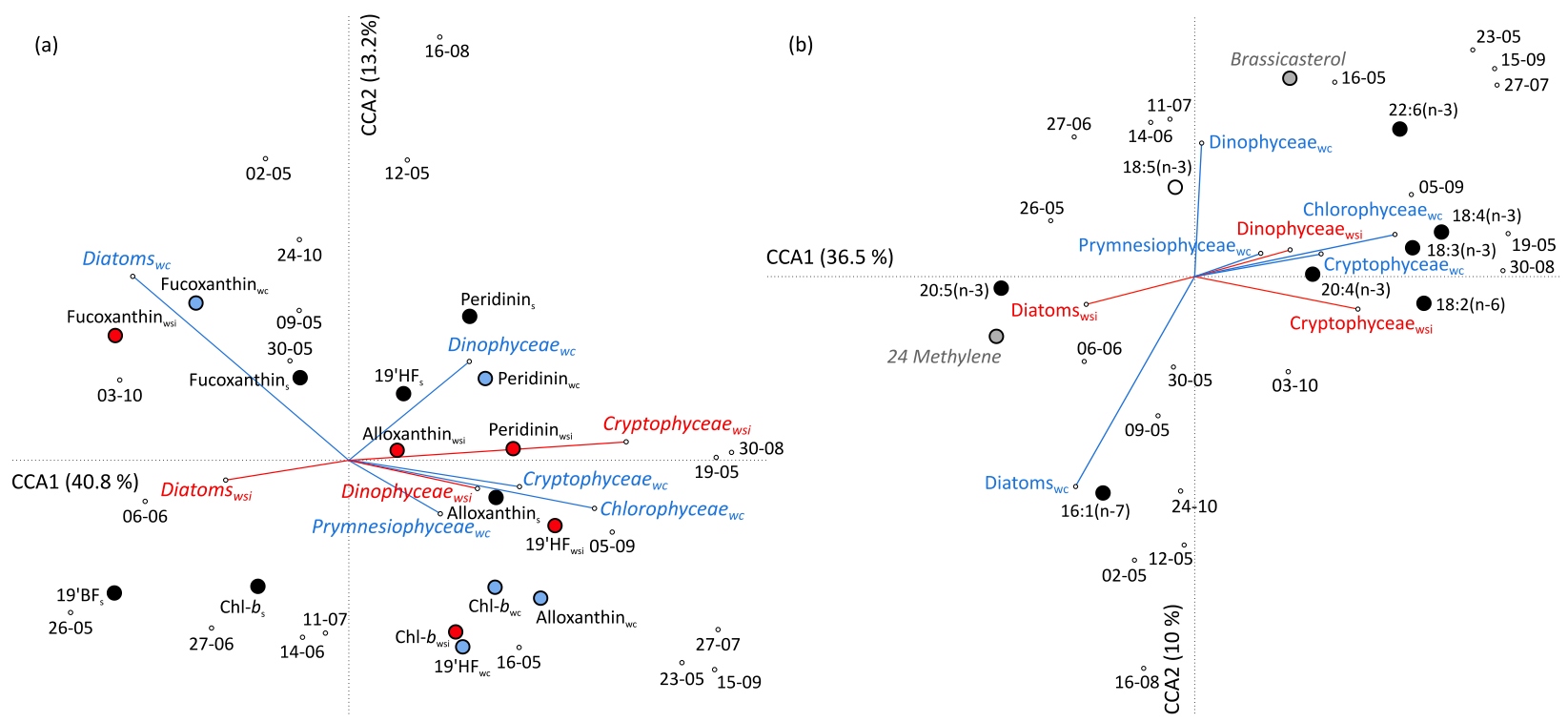

Fig. 8. Triplots from the canonical correspondence analysis performed on pigment and lipid data. Plots include phytoplankton counts in the water column (wc; blue vectors) and the water-sediment interface (wsi; red vectors) and (a) proportions of pigments in the water column (blue dots), the water-sediment interface (red dots) and the stomach contents of Pecten maximus (s; black dots) and (b) proportions of fatty acids from the polar fraction (black dots), the neutral fraction (white dot) and sterols (grey dots) in the digestive gland of $P$. maximus 


\section{Discussion}

\subsection{Validation of pigments as biomarkers}

To our knowledge, the present study is the first to combine the use of pigments, FAs and sterols as food source biomarkers in a seasonal trophic study of a marine suspension-feeding invertebrate. The only other study presenting similar data is by Hurtado et al. (2012), who focused on seasonal dynamics of pigments, FAs and sterols in relation to the reproductive activity of female Crassostrea corteziensis. They concluded that these indicators were relevant when trying to infer energy reserve dynamics, because they are essential membrane components provided by diet and food availability.

There was a clear relationship between pigment concentration and composition in the water and the phytoplankton cell microscopic observations (Fig. 8). The variation of the fucoxanthin proportion corresponded well to each diatom bloom in early May, early June and late September (Fig. 2). Indeed, this pigment has often been reported to highlight the presence of diatoms (Jeffrey 1974, 1997, Mackey et al. 1996, Lampert 2001, Wright \& Jeffrey 2006, Sanz et al. 2015), which contain the most important proportions of this pigment (Lampert 2001). Likewise, the highly variable dynamics of Dinophyceae blooms were very well reproduced by the proportion of peridinin in the water. Alloxanthin proportions recorded in both water compartments precisely matched the identification of Cryptophyceae, which is also in accordance with previous observations (Jeffrey 1974, 1997, Mackey et al. 1996, Lampert 2001, Wright \& Jeffrey 2006, Sanz et al. 2015). The Prymnesiophyceae algae class has been reported to especially contain 19'HF (Jeffrey 1974, 1997, Mackey et al. 1996, Lampert 2001, Wright \& Jeffrey 2006, Sanz et al. 2015), which in the present study seemed to be well correlated with the development of these microalgae. However, cell identification did not fit well with measurements of chl b, a pigment usually linked to Chlorophyceae (Jeffrey 1974, 1997, Mackey et al. 1996, Lampert 2001, Wright \& Jeffrey 2006, Sanz et al. 2015). While the proportion of chl $b$ in the filtered water was rather high during the study (up to $15 \%$ in the water column and $25 \%$ at the bottom, especially during summer), only one bloom of Chlorophyceae was registered in late May. This pigment also constitutes a major component of green macroalgae, which are often observed in the Bay of Brest (Ménesguen et al. 2006). The high concentrations of this pigment in our filtrates could be attributed to discarded pieces of macroalgae in the water (Lampert 2001). The microalgae Lepidodinium chlorophorum, which bloomed between mid-July and mid-August, is also the only known Dinophyceae to contain chl $b$ (Zapata et al. 2012), which is likely to explain the presence of this pigment in the water at this time.

Lipid proportions in the DG fluctuated less than pigment concentrations in the digestive tract content. The incorporation of lipids in the tissues of the organism is a regulated process, smoothed by homeostatic processes and selective incorporation mechanisms (Soudant et al. 1996). On the other hand, pigments are not edible compounds to be assimilated by the scallops (Shuman \& Lorenzen 1975). Most of them are egested within faeces in a more or less degraded form. Considering the properties of these 2 biochemical compounds, the strong changes observed in both FAs from the PLs and sterols were important and indicated critical modifications of the cell membrane of DG tissue, notwithstanding the rather strong homeostasis that would be expected for these structural compounds. Our results indicated stronger variations of FAs from the polar fraction compared to those of the neutral fraction in the DG. In 
this organ, reserve lipids (i.e. NLs) remain relatively unmodified by the diet (Nérot et al. 2015). Measurement of FA composition in other tissues such as the muscle usually focuses on reserve lipids, as dietary FAs are more selectively incorporated into the muscle due to its longer turnover rate (Nérot et al. 2015). Finally, the difference in turnover rate between pigments and lipids in organisms is an advantage which helps overcome the change in sampling frequency (twice a week in April and May, once every $2 \mathrm{wk}$ for the rest of the study), which might impact the temporal variability of data.

\subsection{Feeding ecology}

\subsubsection{Importance of Dinophyceae in the diet of P. maximus}

This study highlights the complexity of the diet of $P$. maximus, both temporally and in terms of composition. During monitoring, the proportion of DHA, representative of Dinophyceae (Parrish et al. 1995, Dalsgaard et al. 2003, Parrish 2013), in the PLs of the DG showed rather important variations. Another FA usually found in some Dinophyceae species is 18:5(n-3) (Dijkman \& Kromkamp 2006), which displayed variations that were very similar to the dynamics of peridinin and DHA. The level of peridinin, a specific pigment of the Dinophyceae (Jeffrey, 1974, 1997, Mackey et al. 1996, Lampert 2001, Wright \& Jeffrey 2006, Sanz et al. 2015), in the digestive tract of $P$. maximus averaged $18 \%$ in the stomach, indicating a significant ingestion of this microalgae class. This is rather surprising as the proportion of peridinin in the water did not exceed $13 \%$. Loret et al. (2000) observed similar results with the oyster Pinctada margaritifera, which actively selected Cryptophyceae despite their relatively low presence in the water. Dinophyceae did not dominate phytoplankton composition in the water, yet biomarkers of this phylum were high in the scallop and showed clear covariation between scallop tissues and the environment (Fig. 8). This suggests that $P$. maximus could be actively selecting Dinophyceae out of the available microalgae mix. DHA and EPA are 2 essential FAs for bivalves (Soudant et al. 1996, 1998b), and DHA is largely present in Dinophyceae and also found in some Prymnesiophyceae (Parrish et al. 1995, Volkman et al. 1998, Dalsgaard et al. 2003, Mansour et al. 2005, Parrish 2013). Foraging on Dinophyceae, even when they are not dominant in the water, could be a way for scallops to get this essential component into their diet. However, these findings conflict with the fact that many Dinophyceae species (not observed during this study) are known for their toxicity. Several studies have reported the negative impacts of blooming events of such microalgae on the physiology of $P$. maximus (Erard-LeDenn et al. 1990, Lorrain et al. 2000, Chauvaud et al. 2001). Not all species of Dinophyceae produce toxins, but they have long been considered as more of a threat than an essential food source for the great scallop (Smolowitz \& Shumway 1997, Lorrain et al. 2000, Chauvaud et al. 2001, Bougrier et al. 2003). P. maximus might be able to select and sort ingested food on a qualitative basis. Suggestions have been made in this way to explain the active selection of food particles in suspension-feeding bivalves, involving ctenidia retention, labial palps sorting and physico-chemical interactions with algal cell surface (Shumway et al. 1985, Ward \& Shumway 2004, Espinosa et al. 2010, Rosa et al. 2013).

Moreover, the great scallop seemed to be able to switch from one source to another depending on the season. Indeed, despite the predominant proportion of diatoms as a food source for scallops, there is an alternation in the stomach content of fucoxanthin, found mainly in diatoms, and peridinin, found exclusively in Dinophyceae (Fig. 4). These shifts are also observed in the FA dynamics (Fig. 6), the 
proportion of 16:1(n-7) and EPA, found in high amounts in diatoms, alternating with the proportion of DHA and 18:5(n-3), representative of Dinophyceae (Dalsgaard et al. 2003). The ratio between EPA and DHA is a common indicator of a diatom- or flagellate-based diet (St. John \& Lund 1996, Auel et al. 2002). The variations of this index are in complete accordance with the evolution of the other biomarkers. Further evidence of this alternation is shown in the evolution of 24 methylene cholesterol and brassicasterol in the DG tissues (Fig. 7), which have also been reported to be major sterols of diatoms and Dinophyceae respectively (Volkman 1986).

While Dinophyceae in the water did not seem to negatively impact ingestion, diatom concentration on the other hand might have stopped feeding activity altogether at some point. During the most important bloom in the water column in early May, proportions of fucoxanthin rapidly increased in the scallops' digestive glands before dropping on 2 May and increasing back to the previous high level $4 \mathrm{~d}$ after. During this bloom, the dominant species were the diatoms Chaetoceros sp., Dactiliosolen fragilissimus, Chaetoceros debilis and Cerataulina pelagica. A temporary stop in diatom ingestion while cell concentrations are at their maximum in the water could result from an overload of sedimenting microalgae. This hypothesis was suggested by Lorrain et al. (2000), who claimed that overly elevated food particles of high quality surrounding the scallop may have a negative effect on filtration and growth. Flocculation is well established as a dominant process in the transport of nutrients to the benthos (Alldredge \& Gotschalk 1989, Cranford et al. 2005), and is particularly significant in supplying food to species such as $P$. maximus that can reside on the continental shelf at depths of up to approximately $220 \mathrm{~m}$ (Nérot et al. 2012). However, the aggregation of blooming microalgae may have caused the scallop to close its valves to prevent/respond to gill clogging. Moreover, these blooming events might lead to oxygen depletion at the bottom, to which the scallop reacts by closing its valves (Taylor et al. 1985, Lorrain et al. 2000).

\subsubsection{Diet switches}

Suspension-feeding bivalves are known to feed mainly on microalgae, filtrated from the surrounding seawater (Le Pennec et al. 2003, MacDonald et al. 2006). The 'bottom-up' relationship between the great scallop and its food implies a feeding plasticity in response to environmental availability. First of all, feeding activity seemed to correlate with phytoplankton dynamics at the water-sediment interface at the beginning of spring, which goes along with the hypothesized ability of $P$. maximus to resuspend microphytobenthos and sedimented microalgae by clapping its valves (Lorrain et al. 2000, Chauvaud et al. 2001, MacDonald et al. 2006). For the rest of the study period, however, the diet of the scallop more closely followed the seston dynamics of the water column, which is also in compliance with a well described benthic-pelagic coupling (Chauvaud et al. 2000, Cranford et al. 2005). More specifically, scallops seemed to feed on Dinophyceae, Prymnesiophyceae, Cryptophyceae and Chrysophyceae, given the proportions of peridinin, 19' HF, alloxanthin and 19'BF in their stomachs until the first large bloom in the water column in early May. This is also supported by the evolution of DHA, found in high proportion in the Dinophyceae (Fig. 8), 18:4(n-3), a common FA in Prymnesiophyceae and 20:4(n-3), rarely found in other microalgae classes than the Cryptophyceae (Volkman et al. 1998, Dalsgaard et al. 2003), even though the latter can result from the elongation of 18:4(n-3). Then, during spring and the renewal of primary production in the water, P. maximus seemed to feed mainly on diatoms and Dinophyceae, 
whose specific pigments respectively account for more than $90 \%$ of the total pigments found in the stomach contents. At the end of May, the proportion of Prymnesiophyceae in the scallops' diet briefly increased, as shown by the ingestion of 19'HF-rich microalgae (Fig. 2) and the accumulation of 18:4(n-3) (Fig. 6). Later, the level of $\mathrm{chl} b$ in the gut of the scallop, which remained under $2 \%$ before the last spring bloom in early June, increased up to $15 \%$ during the first part of summer, indicating an ingestion of green microalgae or green macroalgae debris (Lampert 2001). The FA 18:2(n-6) and 18:3(n-3) in PLs, usually used as trophic signatures of green macroalgae or Chlorophyceae (Jamieson \& Reid 1972, Parrish et al. 1995, Zhukova \& Aizdaicher 1995, Volkman et al. 1998, Dalsgaard et al. 2003, Parrish 2013), showed a fairly smooth increase from June until October. However, this could also reflect an ingestion of Cryptophyceae or Prymnesiophyceae (observed in the seawater at this period), which can also present significant amounts of these FAs (Viso \& Marty 1993, Soudant et al. 1996, Renaud et al. 2002). Finally, at the end of the monitoring period (late September/early October), sharp increases of 24 methylene cholesterol, fucoxanthin and EPA evidenced a diatom based diet.

Zeaxanthin was measured at levels varying between 5 and $10 \%$ in the water, while its contribution to digestive tract contents remained close to zero, except in the first stomach sample and 2 rectum samples in August (Table 2). High levels of zeaxanthin have been reported in cyanobacteria (Jeffrey 1974, 1997, Mackey et al. 1996, Lampert 2001, Wright \& Jeffrey 2006, Sanz et al. 2015), the size of which is under $2 \mu \mathrm{m}$, and in other microorganisms (Grossman et al. 1995). The gill retention capacity of most bivalves is not fine enough to capture such tiny particles (Møhlenberg \& Riisgård 1978, MacDonald et al. 2006, Strohmeier et al. 2012). Nevertheless, several studies have shown evidence that free bacterioplankton, typically ranging in size from 0.3 to $1 \mu \mathrm{m}$, can be ingested and assimilated by Pectinidae and other bivalves when bound in aggregates (McHenery \& Birkbeck 1985, Prieur et al. 1990, Alber \& Valiela 1995, MacDonald et al. 2006, Ward \& Kach 2009). This could explain the occurrence of zeaxanthin in relatively high amounts (3\%) in a few samples. Similarly, the dynamics of iso17:0 FA, a specific marker of marine bacteria (Vestal \& White 1989, Kharlamenko et al. 2001, 2008), in PLs of scallop tissues indicates that bacteria might be part of the diet of $P$. maximus. At certain times of the year, a large proportion (>70\%) of natural particulates of varying size and quality can form aggregates mixed with high molecular weight substances (flocs, marine snow; Alldredge et al. 1993, Crocker \& Passow 1995). More investigations are required to determine if the ingestion of microorganisms could be a way for the scallops to meet energetic requirements when no other trophic sources are available, especially during the bleak season (Quéguiner \& Tréguer 1984).

\subsection{Ingestion, digestion and assimilation}

Some pigments detected in the water did not appear in the same proportions in the scallops' digestive tract. Several experimental studies have pointed out the capacity of $P$. maximus to select different algal species on the basis of their size, nutritional value, physiological state or lipid content (Shumway et al. 1985, Soudant et al. 1998b, Ward \& Shumway 2004). Recently, interactions between some proteins (lectins) of the mucus that covers oysters' gills and carbohydrate present on the surface of microalgae cells have been evidenced (Espinosa et al. 2010) and may contribute to microalgal species selection. Rosa et al. (2013) also highlighted non-specific interactions involving surface-charge and wettability of particles in the particle discrimination process. 
Beyond the matter of ingestion stands the question of the digestion and assimilation of the ingested products. Some pigments found in the stomach were found in the rectum in similar proportions, possibly meaning that the algae they belong to were not digested (Hawkins et al. 1986, Louda et al. 2008). This is the case for fucoxanthin during the month of May and at the end of July or for peridinin in late May and in mid-July to mid-August. $\mathrm{Chl} b$ also seemed to go through the digestive tract rather unaltered, as elevated amounts were found in the rectum, which could reflect a weak affinity to this trophic source. The microalgal cell wall, varying in size, structure and composition among species, might affect the digestibility of phytoplankton.

Pheophorbide- $a$ and pheophytin- $a$ are 2 pigments resulting from the degradation of chl $a$ (Hawkins et al. 1986). Significant amounts (up to $36 \%$ of pheophorbide- $a$ and $25 \%$ of pheophytin- $a$ ) were found in the stomach contents, suggesting that one of the first steps of food processing occurs in this compartment (Fig. 5). In P. maximus, digestion is both extra- and intracellular and occurs at several sites in the digestive tract (Beninger \& Le Pennec 2006). The first step of degradation occurs in the stomach with both a mechanical and chemical action of the crystalline style that breaks and releases enzymes attacking the external layer of the microalgae (sometimes a hard cell wall like the frustule of diatoms). Pigments contained in microalgae undergo different levels of degradation through the enzymatic activity of digestion (Bayne et al. 1987, Pastoureaud et al. 1995). Degradation peaks observed after periods of low ingestion could result from the degradation of the food remains in the stomach and the DG. Indeed, scallops have to cope with periods of low food availability over the winter or between phytoplankton blooms. The degradation of the last food particles in the stomach could provide them with nutrients while awaiting a renewal of food supply. Another possible explanation could be the passive deterioration (not due to active digestion) of the remaining products of digestion inside the stomach.

\subsection{Conclusion}

This in-depth investigation of the seasonal feeding ecology of $P$. maximus shows the species' ability to switch from one trophic source to another. Some food sources seem to be neglected by the great scallop (green algae), in favor of diatoms and dinoflagellates, supporting the hypothesis of food preference (Møhlenberg \& Riisgård 1978, Shumway et al. 1985, Ward \& Shumway 2004, MacDonald et al. 2006, Ward \& Kach 2009, Espinosa et al. 2010, Rosa et al. 2013).

Relating in situ physiological performance to food quantity and quality is not an easy task (Chauvaud et al. 1998, 2001, Lorrain et al. 2000, Strohmeier et al. 2009). Variations in growth performance and survival of scallops rely on numerous environmental factors. An improved description of the dynamics and complexity of energy intake helps with the interpretation of these mechanisms and could be useful in understanding the consequences of ever-changing environments. 


\section{Acknowledgements}

This study has been supported in part by the following: CHIVAS ANR program (Agence Nationale de la Recherche, ANR-Blanc), the COMANCHE ANR program (Agence Nationale de la Recherche, ANR-2010STRA-010) and the Yggdrasil scholarship (Research Council of Norway, grant 211173/F11). The authors gratefully acknowledge the IUEM dive team (Erwan Amice, Isabelle Bihannic, Julien Thébault, Joëlle Richard and Laurent Chauvaud) for deploying and collecting scallops and monitoring probes. We want to thank Charlotte Corporeau, Claudie Quéré and Gauthier Schall for the help in lipids analysis, interpretation of results and fruitful discussions. We also thank Cecile Klein for phytoplankton identification and Aurore Naegelen for providing water samples. We deeply acknowledge Ewan Harney for correction of English writing.

Submitted: September 4, 2017; Accepted: January 4, 2018

Proofs received from author(s): February 20, 2018

\section{References}

Alber, M. and Valiela, I. (1995). Organic aggregates in detrital food webs: incorporation by bay scallops Argopecten irradians. Marine Ecology Progress Series, 121 (1), 117-124.

Alldredge, A.L. and Gotschalk, C.C. (1989). Direct observations of the mass flocculation of diatom blooms: characteristics, settling velocities and formation of diatom aggregates. Deep Sea Research Part I: Oceanographic Research Papers, 36 (2), 159-171.

Alldredge, A.L., Passow, U. and Logan, B.E. (1993). The abundance and significance of a class of large, transparent organic particles in the ocean. Deep Sea Research Part I: Oceanographic Research Papers, 40 (6), 1131-1140.

Auel, H., Harjes, M., da Rocha, R., Stübing, D. and Hagen, W. (2002). Lipid biomarkers indicate different ecological niches and trophic relationships of the Arctic hyperiid amphipods Themisto abyssorum and T. libellula. Polar Biology, 25 (5), 374-383.

Aya, F.A. and Kudo, I. (2017). Nitrogen stable isotopes reveal age-dependent dietary shift in the Japanese scallop Mizuhopecten yessoensis. Isotopes in environmental and health studies 53(1), 80-90.

Bachok, Z., Meziane, T., Mfilinge, P.L. and Tsuchiya, M. (2009). Fatty acid markers as an indicator for temporal changes in food sources of the bivalve Quidnipagus palatum. Aquatic Ecosystem Health \& Management, 12 (4), 390-400.

Bachok, Z., Mfilinge, P.L. and Tsuchiya, M. (2003). The diet of the mud clam Geloina coaxans (Mollusca, Bivalvia) as indicated by fatty acid markers in a subtropical mangrove forest of Okinawa, Japan. Journal of experimental marine biology and ecology, 292 (2), 187-197.

Bayne, B.L., Hawkins, A.J.S. and Navarro, E. (1987). Feeding and digestion by the mussel Mytilus edulis L. (Bivalvia: Mollusca) in mixtures of silt and algal cells at low concentrations. Journal of Experimental Marine Biology and Ecology, 111 (1), 1-22. 
Beninger, P.G. and Le Pennec, M. (2006). Structure and function in scallop. In: Shumway, S. E., G. Jay Parsons, E. (Eds.), Developments in aquaculture and fisheries science. Vol. 35. Elsevier, Ch. 3, pp. 123-228.

Bode, A., Alvarez-Ossorio, M.T. and Varela, M. (2006). Phytoplankton and macrophyte contributions to littoral food webs in the Galician upwelling estimated from stable isotopes. Marine Ecology Progress Series, 318, 89-102.

Bougrier, S., Lassus, P., Bardouil, M., Masselin, P. and Truquet, P. (2003). Paralytic shellfish poison accumulation yields and feeding time activity in the Pacific oyster (Crassostrea gigas) and king scallop (Pecten maximus). Aquatic Living Resources, 16 (4), 347-352.

Chatterjee, A., Klein, C., Naegelen, A., Claquin, P., Masson, A., Legoff, M., Amice, E., L'Helguen, S., Chauvaud, L. and Leynaert, A. (2013). Comparative dynamics of pelagic and benthic micro-algae in a coastal ecosystem. Estuarine, Coastal and Shelf Science, 133, 67-77.

Chauvaud, L., Donval, A., Thouzeau, G., Paulet, Y.-M. and Nézan, E. (2001). Variations in food intake of Pecten maximus (L.) from the Bay of Brest (France): Influence of environmental factors and phytoplankton species composition. Comptes Rendus de l'Académie des Sciences - Series III - Sciences de la Vie, 324 (8), 743-755.

Chauvaud, L., Jean, F., Ragueneau, O. and Thouzeau, G. (2000). Long-term variation of the Bay of Brest ecosystem: benthic-pelagic coupling revisited. Marine Ecology Progress Series, 200, 35-48.

Claustre, H. and Ras, J. (2009). The third seawifs HPLC analysis round-robin experiment (seaharre-3), Chap. 6: The LOV method. NASA technical Memorandum 215849.

Cranford, P.J., Armsworthy, S.L., Mikkelsen, O.A. and Milligan, T.G. (2005). Food acquisition responses of the suspension-feeding bivalve Placopecten magellanicus to the flocculation and settlement of a phytoplankton bloom. Journal of Experimental Marine Biology and Ecology, 326 (2), 128-143.

Crocker, K.M. and Passow, U. (1995). Differential aggregation of diatoms. Marine Ecology Progress Series, 117 (1), 249-257.

Dalsgaard, J., St. John, M., Kattner, G., Müller-Navarra, D. and Hagen, W. (2003). Fatty acid trophic markers in the pelagic marine environment. Advances in marine biology, 46, 225-340.

Dijkman, N.A. and Kromkamp, J.C. (2006). Phospholipid-derived fatty acids as chemotaxonomic markers for phytoplankton: application for inferring phytoplankton composition. Marine Ecology Progress Series, 324 (1), 113125.

Erard-Le Denn, E., Morlaix, M. and Dao, J.-C. (1990). Effects of Gyrodinium cf. aureolum on Pecten maximus (post larvae, juveniles and adults). In Toxic marine phytoplankton. Granéli et al., Editors.

Grossman, A.R., Bhaya, D., Apt, K.E. and Kehoe, D.M. (1995). Light-harvesting complexes in oxygenic photosynthesis: diversity, control, and evolution. Annual review of genetics, 29(1), 231-288.

Hawkins, A.J.S., Bayne, B.L., Mantoura, R.F.C., Llewellyn, C.A. and Navarro, E. (1986). Chlorophyll degradation and absorption throughout the digestive system of the blue mussel Mytilus edulis L. Journal of experimental marine biology and ecology, 96 (3), 213-223.

Hégaret, H., Shumway, E.S., Wikfors, G.H., Pate, S. and Burkholder, J.M. (2008). Potential transport of harmful algae via relocation of bivalve molluscs. Marine Ecology Progress Series, 361, 169-179.

Hurtado, M.A., Racotta, I., Arcos, F., Morales-Bojórquez, E., Moal, J., Soudant, P. and Palacios, E. (2012). Seasonal variations of biochemical, pigment, fatty acid, and sterol compositions in female (Crassostrea corteziensis) oysters 
in relation to the reproductive cycle. Comparative Biochemistry and Physiology Part B: Biochemistry and Molecular Biology, 163 (2), 172-183.

Iverson, S.J., Field, C., Don Bowen, W. and Blanchard, W. (2004). Quantitative fatty acid signature analysis: a new method of estimating predator diets. Ecological Monographs, 74 (2), 211-235.

Jamieson, G.R. and Reid, E.H. (1972). The component fatty acids of some marine algal lipids. Phytochemistry, 11 (4), 1423-1432.

Jeffrey, S.W. (1974). Profiles of photosynthetic pigments in the ocean using thin-layer chromatography. Marine Biology, 26 (2), 101-110.

Jeffrey, S.W. (1997). Phytoplankton Pigments in Oceanography: Guidelines to Modern Methods. UNESCO, Paris.

Kang, C.K., Sauriau, P.-G., Richard, P. and Blanchard, G.F. (1999). Food sources of the infaunal suspension-feeding bivalve Cerastoderma edule in a muddy sandflat of Marennes-Oléron Bay, as determined by analyses of carbon and nitrogen stable isotopes. Marine Ecology Progress Series, 187, 147-158.

Kharlamenko, V.I., Kiyashko, S.I., Imbs, A.B. and Vyshkvartzev, D.I. (2001). Identification of food sources of invertebrates from the seagrass Zostera marina community using carbon and sulfur stable isotope ratio and fatty acid analyses. Marine Ecology Progress Series, 220, 103-117.

Kharlamenko, V.I., Kiyashko, S.I., Rodkina, S.A. and Imbs, A.B. (2008). Determination of food sources of marine invertebrates from a subtidal sand community using analyses of fatty acids and stable isotopes. Russian Journal of Marine Biology, 34 (2), 101-109.

Lavaud, R., Flye-Sainte-Marie, J., Jean, F., Emmery, A., Strand, Ø. and Kooijman, S.A.L.M. (2014). Feeding and energetics of the great scallop, Pecten maximus, through a DEB model. Journal of Sea Research 94, 5-18.

Lampert, L. (2001). Dynamique saisonnière et variabilité pigmentaire des populations phytoplanctoniques dans l'Atlantique Nord (Golfe de Gascogne). Seasonal dynamics and pigmentary variability of phytoplanktonic populations in the Northern Atlantic (bay of Biscay). Ph.D. thesis, University of Brest, Brest.

Le Pennec, M., Paugam, A. and Le Pennec, G. (2003). The pelagic life of the pectinid Pecten maximus - a review. ICES Journal of Marine Science: Journal du Conseil, 60 (2), 211-233.

Loret, P., Pastoureaud, A., Bacher, B. and Delesallel, B. (2000). Phytoplankton composition and selective feeding of the pearl oyster Pinctada margaritifera in the Takapoto lagoon (Tuamotu Archipelago, French Polynesia): in situ study using optical microscopy and HPLC pigment analysis. Marine Ecology Progress Series, 199, 55-67.

Lorrain, A., Paulet, Y.-M., Chauvaud, L., Savoye, N., Donval, A. and Saout, C. (2002). Differential $\delta^{13} \mathrm{C}$ and $\delta^{15} \mathrm{~N}$ signatures among scallop tissues: implications for ecology and physiology. Journal of Experimental Marine Biology and Ecology, 275 (1), 47-61.

Lorrain, A., Paulet, Y.-M., Chauvaud, L., Savoye, N., Nézan, E. and Guérin, L. (2000). Growth anomalies in Pecten maximus from coastal waters (Bay of Brest, France): relationship with diatom blooms. Journal of the Marine Biological Association of the UK, 80 (4), 667-673.

Louda, J.W., Neto, R.R., Magalhaes, A.R.M. and Schneider, V.F. (2008). Pigment alterations in the brown mussel Perna perna. Comparative Biochemistry and Physiology Part B: Biochemistry and Molecular Biology, 150 (4), 385394.

MacDonald, B.A., Bricelj, M.V. and Shumway, S.E. (2006). Physiology: Energy acquisition and utilisation. In Scallops: Biology, Ecology and Aquaculture. Developments in Aquaculture and Fisheries Science, 35, Ch. 7, pp.417-492. 
Mackey, M.D., Mackey, D.J., Higgins, H.W. Wright, S.W. (1996). CHEMTAX a program for estimating class abundances from chemical markers: application to HPLC measurements of phytoplankton. Marine Ecology Progress Series, 14 (1), 265-283.

Mansour, M.P., Frampton, D.M.F., Nichols, P.D., Volkman, J.K. and Blackburn, S.I. (2005). Lipid and fatty acid yield of nine stationary-phase microalgae: Applications and unusual C24-C28 polyunsaturated fatty acids. Journal of Applied Phycology, 17 (4), 287-300.

Marín Leal, J.C., Dubois, S., Orvain, F., Galois, R., Blin, J.-L., Ropert, M., Bataillé, M.-P., Ourry, A. and Lefebvre, S. (2008). Stable isotopes $\left(\delta^{13} C, \delta^{15} \mathrm{~N}\right)$ and modelling as tools to estimate the trophic ecology of cultivated oysters in two contrasting environments. Marine Biology, 153 (4), 673-688.

Mason, J. (1957). The age and growth of the scallop, Pecten maximus (L.), in Manx waters. Journal of the Marine Biological Association of the United Kingdom, 36 (3), 473-492.

McHenery, J.G. and Birkbeck, T.H. (1985). Uptake and processing of cultured microorganisms by bivalves. Journal of Experimental Marine Biology and Ecology, 90 (2), 145-163.

Ménesguen, A., Cugier, P. and Leblond, I. (2006). A new numerical technique for tracking chemical species in a multi-source, coastal ecosystem, applied to nitrogen causing Ulva blooms in the Bay of Brest (France). Limnology and oceanography, 51 (1), 591-601.

Møhlenberg, F. and Riisgård, H.U. (1978). Efficiency of particle retention in 13 species of suspension feeding bivalves. Ophelia, 17, 239-246.

Napolitano, G.E., Ackman, R.G. and Silva-Serra, M.A. (1993). Incorporation of dietary sterols by the sea scallop Placopecten magellanicus (Gmelin) fed on microalgae. Marine Biology, 117, 647-654.

Nérot, C., Lorrain, A., Grall, J., Gillikin, D.P., Munaron, J.-M., Le Bris, H. and Paulet, Y.-M. (2012). Stable isotope variations in benthic filter feeders across a large depth gradient on the continental shelf. Estuarine, Coastal and Shelf Science, 96, 228-235.

Nérot, C., Meziane, T., Schaal, G., Grall, J., Lorrain, A., Paulet, Y.-M. and Kraffe, E. (2015). Spatial changes in fatty acids signatures of the great scallop Pecten maximus across the Bay of Biscay continental shelf. Continental Shelf Research, 109, 1-9.

Oksanen, J., Blanchet, F.G., Friendly, M., Kindt, R., Legendre, P., McGlinn, D., Minchin, P.R., O'Hara, R.B., Simpson, G.L., Solymos, P., Stevens, M.H.H., Szoecs, E. and Wagner, H. (2017). Vegan: Community Ecology Package. R package version 2.4-3.

Espinosa, P.E., Perrigault, M., Ward, J.E., Shumway, S.E. and Allam, B. (2010). Microalgal cell surface carbohydrates as recognition sites for particle sorting in suspension-feeding bivalves. The Biological Bulletin, 218 (1), 75-86.

Parrish, C.C. (2013). Lipids in marine ecosystems. ISRN Oceanography, 2013.

Parrish, C.C., McKenzie, C.H., MacDonald, B.A. and Hatfield, E.A. (1995). Seasonal studies of seston lipids in relation to microplankton species composition and scallop growth in South Broad Cove, Newfoundland. Marine Ecology Progress Series, 129, 151-164.

Pastoureaud, A., Heral, M., Prou, J., Razet, D. and Russu, P. (1995). Particle selection in the oyster Crassostrea gigas (Thunberg) studied by pigment HPLC analysis under natural food conditions. Aquaculture, 19 (1), 79-88.

Prieur, D., Mevel, G., Nicolas, J.L., Plusquellec, A. and Vigneulle, M. (1990). Interactions between bivalve molluscs and bacteria in the marine environment. Oceanography Marine Biology Annual Revue, 28, 277-352. 
Quéguiner, B. and Tréguer, P. (1984). Studies on the phytoplankton in the Bay of Brest (Western Europe). Seasonal variations in composition, biomass and production in relation to hydrological and chemical features (1981-1982). Botanica Marina, 27, 449-459.

R Core Team (2013). R: A language and environment for statistical computing. R Foundation for Statistical Computing, Vienna, Austria.

Raikow, D.F. and Hamilton, S.K. (2001). Bivalve diets in a midwestern US stream: a stable isotope enrichment study. Limnology and Oceanography, 46 (3), 514-522.

Renaud, S.M., Thinh, L.-V., Lambrinidis, G. and Parry, D.L. (2002). Effect of temperature on growth, chemical composition and fatty acid composition of tropical Australian microalgae grown in batch cultures. Aquaculture, 211 (1), 195-214.

Roditi, H.A., Fisher, N.S. and Sañudo Wilhelmy, S.A. (2000). Uptake of dissolved organic carbon and trace elements by zebra mussels. Nature, 407 (6800), 78-80.

Rosa, M., Ward, J.E., Shumway, S.E., Wikfors, G.H., Espinosa, P.E. and Allam, B. (2013). Effects of particle surface properties on feeding selectivity in the eastern oyster Crassostrea virginica and the blue mussel Mytilus edulis. Journal of Experimental Marine Biology and Ecology, 446, 320-327.

Rossi, F., Herman, P.M.J. and Middelburg, J.J. (2004). Interspecific and intraspecific variation of $\delta^{13} \mathrm{C}$ and $\delta^{15} \mathrm{~N}$ in deposit- and suspension-feeding bivalves (Macoma balthica and Cerastoderma edule): Evidence of ontogenetic changes in feeding mode of Macoma balthica. Limnology and Oceanography, 49 (2), 408-414.

Sanz, N., García-Blanco, A., Gavalás-Olea, A., Loures, P. and Garrido, J.L. (2015). Phytoplankton pigment biomarkers: HPLC separation using a pentafluorophenyloctadecyl silica column. Methods in Ecology and Evolution, 6(10), 1199-1209.

Shuman, F.R. and Lorenzen, C.J. (1975). Quantitative degradation of chlorophyll by a marine herbivore. Limnology and Oceanography, 20 (4), 580-586.

Shumway, S.E., Cucci, T.L., Newell, R.C. and Yentsch, C.M. (1985). Particle selection, ingestion, and absorption in filter-feeding bivalves. Journal of experimental marine biology and ecology, 91 (1), 77-92.

Shumway, S.E., Selvin, R. and Schick, D.F. (1987). Food resources related to habitat in the scallop Placopecten magellanicus (Gmelin, 1791): a qualitative study. Journal of Shellfish Research, 6 (2), 89-95.

Smolowitz, R. and Shumway, S.E. (1997). Possible cytotoxic effects of the dinoflagellate, Gyrodinium aureolum, on juvenile bivalve molluscs. Aquaculture International, 5 (4), 291-300.

Soudant, P., Le Coz, J.-R., Marty, Y., Moal, J., Robert, R. and Samain, J.-F. (1998a). Incorporation of microalgae sterols by scallop Pecten maximus (L.) larvae. Comparative Biochemistry and Physiology-Part A: Molecular \& Integrative Physiology, 119 (2), 451-457.

Soudant, P., Marty, Y., Moal, J., Masski, H. and Samain, J.-F. (1998b). Fatty acid composition of polar lipid classes during larval development of scallop Pecten maximus (L.). Comparative Biochemistry and Physiology Part A: Molecular \& Integrative Physiology, 121 (3), 279-288.

Soudant, P., Marty, Y., Moal, J., Robert, R., Quéré, C., Le Coz, J.-R. and Samain, J.-F. (1996). Effect of food fatty acid and sterol quality on Pecten maximus gonad composition and reproduction process. Aquaculture, 143 (3-4), 361378. 
Soudant, P., Marty, Y., Moal, J. and Samain, J. F. (1995). Separation of major polar lipids in Pecten maximus by highperformance liquid chromatography and subsequent determination of their fatty acids using gas chromatography. Journal of Chromatography B: Biomedical Sciences and Applications, 673 (1), 15-26.

St. John, M. and Lund, T. (1996). Lipid biomarkers: linking the utilization of frontal plankton biomass to enhanced condition of juvenile North Sea cod. Marine Ecology-Progress Series, 131 (1-3), 75-85.

Strohmeier, T., Strand, $\varnothing$., Alunno-Bruscia, M., Duinker, A. and Cranford, P.J. (2012). Variability in particle retention efficiency by the mussel Mytilus edulis. Journal of Experimental Marine Biology and Ecology, 412, 96-102.

Taylor, F.J., Taylor, N.J. and Walsby, J.R. (1985). A bloom of the planktonic diatom, Cerataulina pelagica, off the coast of northeastern New Zealand in 1983, and its contribution to an associated mortality of fish and benthic fauna. Internationale Revue der gesamten Hydrobiologie und Hydrographie, 70 (6), 773-795.

Vestal, J.R. and White, D.C. (1989). Lipid analysis in microbial ecology. Bioscience, 39 (8), 535-541.

Viso, A.-C. and Marty, J.-C. (1993). Fatty acids from 28 marine microalgae. Phytochemistry, 34 (6), 1521-1533.

Volkman, J.K. (1986). A review of sterol markers for marine and terrigenous organic matter. Organic Geochemistry, $9(2), 83-99$.

Volkman, J.K., Barrett, S.M., Blackburn, S.I., Mansour, M.P., Sikes, E.L. and Gelin, F. (1998). Microalgal biomarkers: A review of recent research developments. Organic Geochemistry, 29 (5-7), 1163-1179.

Ward, J.E. and Kach, D.J. (2009). Marine aggregates facilitate ingestion of nanoparticles by suspension-feeding bivalves. Marine Environmental Research, 68 (3), 137-142.

Ward, J.E. and Shumway, S.E. (2004). Separating the grain from the chaff: particle selection in suspension- and deposit-feeding bivalves. Journal of Experimental Marine Biology and Ecology 300 (1-2), 83-130.

Wright, S.W. and Jeffrey, S.W. (2006). Pigment markers for phytoplankton production. In Marine organic matter: biomarkers, isotopes and DNA. Springer, Berlin, Heidelberg. pp 71-104.

Zapata, M., Fraga, S., Rodríguez, F. and Garrido, J.L. (2012). Pigment-based chloroplast types in dinoflagellates. Marine Ecology Progress Series, 465, 33-52.

Zhukova, N.V. and Aizdaicher, N.A. (1995). Fatty acid composition of 15 species of marine microalgae. Phytochemistry, 39 (2), 351-356. 